\title{
Covid-19 Response of an Additive Manufacturing Cluster in Australia
}

\author{
Tillmann Boehme, James Aitken, Neil Turner and Robert Handfield
}

\begin{abstract}
Purpose - The sudden arrival of Covid-19 severely disrupted the supply chain of Personal Protective Equipment (PPE) in Australia. This research examines the development of a geographical cluster which, through the application of additive manufacturing (AM), responded to the PPE supply crisis.
\end{abstract}

Design/Methodology/approach - This longitudinal case study focuses on an AM cluster which was developed to supply PPE in a responsive and flexible manner from 2019/2020. The study gathered data over three stages of cluster evolution: pre, during and post peak Covid-19.

Findings - The type and nature of exchanges between organizations involved in the cluster established important insights into success factors for cluster creation and development. Using an established complexity framework, we identified the characteristics of establishing a cluster. The importance of cluster alignment created initially by a common PPE supply goal led to an emerging commercial and relational imperative to address the longer-term configuration after the disruption.

Originality/value - Covid-19 has rapidly and unexpectedly disrupted the supply chain for many industries. Responding to challenges, businesses will investigate different pathways to improve their overall resilience including on-/ near-shoring. Our results provide insights into how clusters are formed, grow, and develop, and the differentiating factors that result in successful impacts of clusters on local economies.

Practical Implications - Clusters can be a viable option for a technology-driven sector when there is "buzz" that drives and rapidly diffuses knowledge to support cluster formation. This research identifies the structural, socio-political and emergent dimensions, which need to be considered by stakeholders when aiming at improving competitiveness using clusters.

Keywords: Covid-19, Complexity, Additive Manufacturing, Geographical Clusters, Disaster Relief

Paper Type Research paper 


\subsection{Introduction}

Covid-19 exposed the vulnerability of the global supply chain of personal protective equipment (PPE) such as masks, and the lack of supply chain resilience developed by the Australian healthcare sector (Corsini et al, 2021; Handfield et al., 2020;). The substantial increase in demand for PPE exhausted many countries' national stockpiles used to cope with extreme healthcare epidemics (Papalexi et al., 2019). In the case of Australia, Covid-19 healthcare supply disruptions resulted in the introduction of rapid assessment procedures by government for a range of medical devices including PPE (Clay-Williams et al., 2020). The shortfall of supply was addressed through industrial manufacturers converting production to life-saving equipment. The rapid on-shoring of production led to the localization of PPE production through the formation of an additive manufacturing (AM) healthcare cluster. We document this cluster in this research.

AM clusters have a history of providing critical product support for emergency situations, including humanitarian disaster relief. According to Kovacs and Spens (2007), disaster relief operations typically produce widespread shortages of food and healthcare supplies due to problems associated with unexpected demand, supply shortages and fulfilment complexity. In disaster regions, demand is unpredictable regarding timing, location, and scale (Beamon, 2004; John et al., 2012), shortages of relief material, fuel for transportation, and handling equipment (John et al., 2012). In March of 2020, many of these operational issues occurred during the peak of the Covid-19 crisis in Australia. AM in these circumstances can serve an important role due to its agility and the flexibility of the technology. Mohr and Khan (2015) note that AM can provide benefits along several performance characteristics: mass customization, resource efficiency, decentralization of manufacturing, complexity reduction, rationalization of inventory and logistics, product design and prototyping, and legal and security concerns. With decentralized manufacturing, production units can be located near points of consumption, thereby enabling quick responses to rapid shifts in demand (Rylands et al., 2016). According to Tatham et al. (2015), the decentralized nature of AM is particularly useful in disaster relief because production units can rapidly provide customized relief materials in the face of uncertain demand. When decentralized AM production is coordinated and bundled in clusters, the impact and benefit of the technology is even more impactful. Decentralized AM clusters strengthen overall supply chain resilience, by reducing dependence on global suppliers with long lead times and provide more agile response capabilities for emergency requirements (Tatham et al., 2015). In this paper we add to this literature regarding the response to the Covid-19 pandemic response.

On a more general level, industry clusters (both manufacturing and non-manufacturing) provide a number of other benefits in the long term. Such clusters can support and strengthen local economies, due to dynamic value networks that establish new economic improvements for local geographies. Silicon Valley in California and the fashion district in Treviso (Northern Italy) (Aage \& Belussi, 2008) represent two examples of the positive impact of clusters on long-term economic growth and performance. When not properly sustained however, examples of cluster declines can be observed in the cases of the watch industry in Jura (Switzerland) (Crespo 2011) and the textile industry in Daegu (South Korea) (Hassink, 
2005). The factors lying behind the success or failure of cluster networks remains an important question for research. We believe that the answers lie in the analysis of how geographic clusters are formed, grow, and develop, as well as the differentiating factors that result in successful long-term impacts. We sought to explore and understand these attributes in more detail in our research within an Australian manufacturing cluster.

Despite the growing interest of scholars in understanding the long-term economic impact and disaster response capability of AM clusters (Bitici et al., 2004; Hammervoll et al., 2014), gaps exist in the literature on several fronts. For instance, scholars are calling for a deeper understanding of the role of geography in shaping the structure and process of cluster networks (Novak and Choi, 2015). There are also gaps in understanding how AM clusters evolve and are formed (Jin et al., 2017), and the role of coopetition in such clusters (Schiffling et al., 2020).

We explore the dynamics of AM cluster development through a longitudinal case study during the Covid19 pandemic focusing on an Australian AM healthcare cluster, to document and better understand the mechanisms that supported its formation and evolution. This addresses a call by Battaglia et al (2021) to investigate longitudinally the role ecosystems perform in sustaining organizations that arise out of Covid19 turbulent times. The paper identifies the characteristics of the cluster, employing a supply chain complexity lens (Turner et al., 2018) to understand barriers and enablers within this healthcare operation. Our findings develop important insights regarding the characteristics of this successful additive manufacturing cluster and their role in supporting logistics during the crisis that faced Australian healthcare workers during the Covid-19 pandemic. These findings provide some generalizable insights that may be applied to future humanitarian disasters and emerging technology responses.

The structure of this paper is as follows. First, we review prior literature on the current landscape of ecosystems and clusters in general, as well as additive manufacturing clusters, and what we know about what makes them successful. Next, we describe our methodology and the findings from our empirical data. The paper concludes with a discussion of theoretical contributions and future research opportunities on the topic.

\subsection{Literature Review}

\subsection{Clusters and ecosystems}

Scholars have long sought to understand how organizations come together to meet existing or expected customers' needs (Gawer, 2014). Literature provides insights into the formation of ecosystems which have emerged in response to market changes and demands (Dedehayir et al. 2018). Bogers et al. (2019, p.2) define the term ecosystem as "an interdependent network of self-interested actors jointly creating value". Here organizations work together to coordinate complementary resources and through this interaction exchange services and products to ensure that the requirements of their customers are addressed (Jacobides et al., 2018; Vargo and Lusch, 2017). This complementarity of interests is what distinguishes ecosystems from other forms of governance, and greater complementarities make it easier to align interests (Kapoor \& Lee, 2013). Bogers et al. (2019) argue that ecosystem success is dependent on three 
factors. First, the goals of the members are important, as membership must align with their interests. Second, interdependence (the relationship between the members) is critical for value creation. The relationships are most likely to be complementary and cooperative, working towards a common goal, but can be competitive if specific niches within the ecosystem are sought. Third, the attributes of structure and governance (whether decentralised or centralised) are valuable to longer-term viability. Bogers et al. (2019) also identify that a research agenda should include work looking at network and member goals, and the role governance plays in these goals. Dedehayir et al. (2016) similarly examined the genesis or pioneering stage of ecosystems and the roles that underpin their formation including: leadership which sets the direction and vision; regulator developing governance; expert producing ideas; and champion driving results.

Rong et al. (2020) look at strategic choices and manufacturing capabilities in the context of 3D printing ecosystems, and Cui et al. (2019) identify how a 3D printing firm developed its business ecosystem, moving from a peripheral to a core position in its own digital ecosystem. Kwak et al. (2018) look specifically at a 3D-printing ecosystems and identify what they term a 'complementary multiplatform' approach. This involves four elements: open-source hardware platforms; online service platforms; free and low-cost 3D design software platform; and crowdsourcing platforms, which together support the growth of the ecosystem. The importance of innovative ecosystems in arenas such as IT is clearly recognized in the literature (e.g. Parker et al., 2017). Debates exists regarding the strength of linkages between ecosystems, innovation clusters and networks (Oh et al., 2016). Some researchers (e.g. Finegold, 1999) have used ecosystem concepts in examining interdependence within a given location, such as a regional technology cluster. However, authors such as Dedehayir et al. (2018) specify that a cluster must have a regional focus for its activities. Ecosystems and clusters have many overlapping properties, however they differ in terms of their boundaries. Innovation ecosystems are defined by collective functionality, not geography. Geographically adjacent clusters of organizations within the same industry have been shown, due to proximity, to help foster knowledge and intellectual capital through both competition and collaboration (Ahn and Meeks, 2008). The catalyst for successful clustering has been shown to be "persistent communication, knowledge sharing, and transparency" (McPhillips 2020, p.7). The focus of this paper is on a geographically close cluster, which sought to deploy AM to address a specific supply chain issue that arose as a result of PPE shortages.

According to Porter (1998, p.197), clusters are "geographic concentrations of interconnected companies, specialized suppliers, service providers, firms in related industries, and associated institutions (for example, universities, standard agencies, and trade associations) in particular fields that compete but also co-operate". As a result, companies operating in a cluster may demonstrate both cooperative and competitive behaviours. The essential role of organizations involved in clusters is to create the conditions, including increased trust, alignment and reduced information asymmetries, for the successful integration of SMEs in external cooperation (Adner, 2017; Engel 2015; Nestle et al., 2019).

Researchers over the last twenty years have refined the characteristics of geographical clusters to provide an explanation of the relevant components that influence their formation and development. Fraser and Kelly (2010) identify nine success components, and we document and expand on these with additional literature in Table 1. Some of the most important characteristics include the presence of a large and 
influential organization (Chetty et al., 2018), such as research institutes and multinationals, which can play a significant role in instigating and developing clusters. Researchers have identified the innovative intermediary role of clusters bringing together business organizations, academic institutions and regional government (Kivimaa et al., 2019). Second, the emergence of demand (Ingstrup et al., 2017) which is geographically proximate is important, especially during emergency situations such as pandemics. Third, the "buzz" generated by face-to face interactions of geographically close organizations can drive investment and collaboration (Frazer and Kelly, 2010). We define "buzz" as the intense interaction of colocalised actors that develop a knowledge-based ecosystem through traded and untraded interdependencies (Bathelt et al., 2004; Henn and Bathlet, 2018). Other factors include innovative technology specialization (Vernay et al., 2019), the presence of a sophisticated workforce, financial and educational intermediary support (Pan, 2019), and a channel of communication which connects the cluster to outside resources. Each of the nine components are described in greater detail in Table I.

Table I. Components of clusters (adapted from Fraser and Kelly, 2010)

\begin{tabular}{|c|c|c|}
\hline $\begin{array}{l}\text { Success } \\
\text { Components }\end{array}$ & Description & References \\
\hline $\begin{array}{l}\text { Large pillar } \\
\text { firm presence }\end{array}$ & $\begin{array}{l}\text { Facilitates communication and collaboration as well as } \\
\text { providing support for start-ups and boosting credibility }\end{array}$ & $\begin{array}{l}\text { Chetty et al 2018; } \\
\text { Fraser and Kelly, } 2010\end{array}$ \\
\hline Local demand & $\begin{array}{l}\text { Can emerge due to a "window of locational opportunity" } \\
\text { created by exogenous triggers, reflecting the need for } \\
\text { demand to ensure cluster growth. }\end{array}$ & $\begin{array}{l}\text { Ingstrup et al., 2017; } \\
\text { Fornahl et al., } 2010\end{array}$ \\
\hline $\begin{array}{l}\text { Key } \\
\text { agents/Local } \\
\text { company } \\
\text { linkages }\end{array}$ & $\begin{array}{l}\text { Generally, from large pillar firms or education and research } \\
\text { institutes. Provide advice, consultation, education and } \\
\text { mentoring support as well as venture capital funds. Key } \\
\text { agents can act as intermediaries and knowledge brokers. }\end{array}$ & $\begin{array}{l}\text { Pan 2019; Smedlund, } \\
2006\end{array}$ \\
\hline $\begin{array}{l}\text { Regional } \\
\text { specialization }\end{array}$ & $\begin{array}{l}\text { Enables local/central government in identifying relevant } \\
\text { support to develop specialism and expertise for a region. } \\
\text { Creating and supporting specialist zones }\end{array}$ & $\begin{array}{l}\text { Vernay et al., 2018, } \\
2019\end{array}$ \\
\hline $\begin{array}{l}\text { Local } \\
\text { academic links }\end{array}$ & $\begin{array}{l}\text { Supporting the needs of local businesses through research } \\
\text { centres and specialist executive training courses }\end{array}$ & $\begin{array}{l}\text { Pan, 2019; Fraser and } \\
\text { Kelly, 2010 }\end{array}$ \\
\hline $\begin{array}{l}\text { Sophisticated } \\
\text { workforce }\end{array}$ & $\begin{array}{l}\text { Highly skilled labour important as a precondition for the } \\
\text { growth of innovative clusters. Specialized training required } \\
\text { through academic support }\end{array}$ & $\begin{array}{l}\text { Fornahl et al., 2010; } \\
\text { Bresnahan et al., } 2001\end{array}$ \\
\hline $\begin{array}{l}\text { Management } \\
\text { skills }\end{array}$ & $\begin{array}{l}\text { Lack of management and commercialization skills in small } \\
\text { enterprises can limit cluster development. Successful } \\
\text { clusters need to possess resources and skills that they can } \\
\text { use to strengthen their performance }\end{array}$ & $\begin{array}{l}\text { Colvic, 2019; Fraser } \\
\text { and Kelly, } 2010\end{array}$ \\
\hline Buzz & $\begin{array}{l}\text { Refers to the information and communication ecology } \\
\text { created by face-to-face contacts, co-presence and co- } \\
\text { location of people and firms within the same industry and } \\
\text { place or region. Buzz is spontaneous, dynamic and can } \\
\text { rapidly diffuse knowledge and information through a local } \\
\text { cluster. }\end{array}$ & $\begin{array}{l}\text { Bathelt et al., 2004; } \\
\text { Fraser and Kelly, } 2010\end{array}$ \\
\hline Pipelines & $\begin{array}{l}\text { The act of building channels of communication to selected } \\
\text { agents outside of the cluster to build knowledge. These }\end{array}$ & Fraser and Kelly, 2010 \\
\hline
\end{tabular}


pipelines which can bring knowledge to the cluster can be

local, regional, national or global.

Supply chain management scholars have been particularly interested in industrial clusters (deWitt et al., 2006; Huang and Xue, 2012; Kayvanfar et al., 2019). Since clusters are formed by geographically proximate multiple enterprises, connected together in the value chain by a number of upstream and downstream integration mechanisms, they provide a platform for the creation of relationships between different members of diverse supply chains (Huang and Xue, 2012). For instance, deWitt et al. (2006) noted that: "clusters can be thought of as geographic concentrations of competing, networked supply chains" ( $p$. 305). Companies operating in a cluster can benefit from increased responsiveness to market change, reduced customer search costs (Breschi and Beaudry, 2003) and greater economies of scale that go beyond the capacity of an individual business (Huang and Xue, 2012).

Clustered supply chains have three important elements in common: (1) geographical concentration increases cost efficiencies of supply chain coordination (deWitt et al., 2006) and enhances competitive drive, trust and innovation among companies (Huang and Xue, 2012); (2) vertical and horizontal cooperation allows firms operating in a cluster supply chain to benefit from advantages of scale without dealing with the increased relational complexity associated with typical vertical integration mechanisms (Huang and Xue, 2012); (3) cluster supply chains are characterized by service-center patterns which support coordination among companies along the value chain (Huang and Xue, 2012). However, academic articles that examine how and why these clusters are initially formed and subsequently developed are very limited compared to the ecosystems literature (Dedehayir et al., 2018; Dedehayir et al., 2016). Our research through examining an AM cluster which alters in response to supply chain disruption will add to the knowledge of these geographically bounded networks.

\subsection{Additive Manufacturing Clusters}

The emergence of additive manufacturing (AM) clusters is a fairly recent development in the history of clusters. AM clusters can support the adoption and implementation of AM technology in the manufacturing sector (Tatham et al., 2015). Two prominent American clusters developed in the geographical locations of Ohio and Pittsburgh, two historical US manufacturing strongholds of the 1980's. The AM cluster of Ohio incorporates companies such as YBI (Youngstown Business Incubator), TeamNEO, America Makes, MAGNET, Jumpstart and Youngstown State University. The cluster was formed to drive business and economic growth throughout the Northeast Ohio supply chain by adopting AM (Ohio AM, 2020). The formation of the Pittsburgh "Neighborhood 91" cluster was announced in November 2019 by the Pittsburgh International Airport, and served as a catalyst for AM industrialization and innovation with the creation of an ecosystem. This cluster is predicted to generate $\$ 2.2 \mathrm{~B}$ in wages and 6000 jobs (3D Printing Industry, 2020a).

Other prominent cases appear in Europe and Asia such as the AM open cluster in Bavaria consisting of the Technical University of Munich (TUM), Oerlikon, GE Additive and Linde as the participants. This was designed as an open cluster where the universities involved were responsible for both research and teaching in AM technology (3D Print, 2020). The National Additive Manufacturing Innovation Cluster in 
Singapore is a national programme initiative led by NTUitive. The cluster consists of universities which include Nanyang Technological University, National University of Singapore and Singapore University of Technology and Design, and technology partners such as A* SIMTECH, Nanyang Polytechnic, Temasek Polytechnic, and Singapore Polytechnic. The universities will work within the cluster to keep encouraging innovators and designers as they are involved in projects like creating start-ups as well as spinoffs from other businesses. The aim of the cluster is to address barriers to AM adoption and provide access to AM technologies, knowledge, and development funding (3D Printing Industry, 2020b).

An important common element within all of these clusters is the combined research activity on AM technology through collaboration between industry and research institutions. Prior studies suggest that a positive interaction occurs between technology-driven firms and research institutions in the development of AM clusters (Henn and Bathelt, 2018). The combination of industry and academia seems to create local knowledge-based ecologies that can support the transfer of technical as well as managerial skills in cluster development (Fraser and Kelly, 2010)

\subsection{AM Cluster Complexity Framework}

A significant increase in AM activity occurred during the Covid-19 pandemic, due to the extreme disruptions in global supply chains. Covid-19 created significant uncertainty in the supply chains of many industries, particularly healthcare. Uncertainty in terms of upstream supplier performance and downstream customer demand led to critical shortfalls of PPE across the globe as the outbreak was classified as a pandemic in early 2020 (Handfield et al., 2020). In response, healthcare practitioners altered their internal procedures and processes to accept supply of PPE from multiple sources, leading to a broadening of the supply base, widening of contacts and proliferation of products. Normally, the rapid expansion of suppliers, products and adaptation of processes is viewed as dysfunctional, based on normal paradigms of operations complexity (Bozarth et al., 2009). However, during the pandemic, massive trauma in the healthcare supply chain called for unusual activities; suddenly, the resulting dysfunctional complexity (Aitken et al., 2016) was accepted as necessary and important for an appropriate national response to an emergency in Australia (Clay-Williams et al., 2020). The significant changes to the PPE supply chain suddenly altered how managers viewed complexity, in terms of its source (internal/external), the form such complexity takes (number of products/suppliers and related uncertainties), and its nature (dysfunctional/beneficial). The use of a complexity lens, to understand the drivers and challenges faced by AM organizations responding to supply chain PPE shortages, thus appeared to be appropriate for our investigation.

Various forms of supply chain complexity and managerial approaches to addressing them (either as standalone projects or as on-going activities) have been researched extensively in recent years (Aitken et al., 2016; Bozarth et al., 2009; Serdarasan 2013; Turner et al., 2018). To analyze the formation and operation of an AM supply chain cluster we relied on an existing theoretical framework for documenting project/supply chain complexity to characterize the actions of the multiple participants as they formed an AM cluster in response to Covid-19. As part of our analysis, we sought to explore the 'technical' aspects of the managerial actions and their evolution over time, as well as the subtler 'social' elements to develop a more holistic set of insights regarding the forces at work. This is in line with recent research that 
recommends adopting a social capital lens in investigating supply chain challenges (e.g. Daghar et al., 2021).

We rely on the work of Turner et al. (2018) who recently adopted this complexity framework to characterize the specific challenges faced by supply chain managers and the practical responses to different complex situations. Our approach is grounded in prior methodological traditions that emphasize a rich 'lived experience' for documenting managers' perceptions of the situation(s) they face (Cicmil et al., 2009; Williams, 2005), rather than an objective external assessment. This approach is also grounded in the methodological discipline of unobtrusive measures in the social sciences (Webb et al., 1966).

The complexity model used to frame the development of the AM cluster in our case study is based on Maylor et al. (2013). Building on the review of Geraldi et al. (2011), and using empirical evidence from a range of managers, they created the Complexity Assessment Tool (CAT), which identified the major barriers managers faced when managing projects. Maylor et al. (2013) identified three specific categories of complexity:

"(1) Structural complexity: increases with the number of people involved, financial scale, number of interdependencies within and without, variety of work being performed, pace, breadth of scope, number of specialist disciplines involved, number of locations and time-zones.

(2) Socio-political complexity: increases with the divergence of people involved, level of politics or power-play to which the project is subjected, lack of stakeholder/sponsor commitment, degree of resistance to work being undertaken, lack of shared understanding of the project goals, lack of fit with strategic goals, hidden agendas, conflicting priorities of stakeholders.

(3) Emergent complexity: increases with novelty of project, lack of technological and commercial maturity, lack of clarity of vision/goals, lack of clear success criteria/ benefits, lack of previous experience, failure to disclose information, rising to prominence of previously unidentified stakeholders, any changes imposed on or by the project." (Maylor and Turner, 2017, p.1080).

To summarize, these three dimensions deal with structural challenges, people problems, and events that arise from a lack of knowledge over the course of a project.

The emergence of an AM cluster that acts in response to supply chain disruption would be expected to face similar challenges as managers provide practical responses to evolving complex situations. Structural complexity is driven by multiple independent and interdependent specialist organizations clustering together to perform a variety of work, including sales, production, design and product architecture, within a geographically localised area across multiple sites (Chetty et al., 2018; Dedehayir,2018; Vernay et al., 2019). In terms of the supply chain the types of structural complexity that the AM cluster could face were identified by Bozarth et al. (2009) as 'detail complexity', encompassing the number of products, components and actors (suppliers and customers) that make up the system. Product architecture complexity has also been shown as a constraint in responding to supply chain disruption (Elsahn and Siedlok, 2021).

Socio-political complexity derives from an initial lack of shared understanding of roles and responsibilities, combined with a requirement to diffuse knowledge within and across organizational boundaries and 
develop skills to strengthen the cluster (Ahn and Meeks, 2008; Colvic, 2019; Fraser and Kelly, 2010). The supply chain literature recognises complexity can arise across internal and external boundaries. Internally derived complexity can be addressed through alignment of functional objectives and the flow of information (de Leeuw et al., 2013) requiring management skills in the cluster to strengthen performance and communication (Fraser and Kelly, 2010). Complexity across organizational boundaries can be managed through external integration approaches (Aitken et al., 2016). For the AM cluster this could be through the interaction between network actors/producers and a research institution (Henn and Bathelt, 2018).

Bode and Wagner (2015, p. 216) define supply chain disruptions as "unplanned and unanticipated events that disrupt the normal flow of goods and materials within a supply chain". Disruptive events can create commercial opportunities (Corsini et al., 2021) as well as emergent complexity challenges (Bode and Wagner, 2015) to organizations within the supply chain. Emergent complexity can arise for the cluster as it changes focus to address the supply chain disruption opportunity, combined with an initial lack of technical and managerial skills required to operate a cluster that can meet the rigorous standards of the health care sector (Adner, 2017; Engel, 2015; Ingstrup et al., 2017; Nestle et al., 2019). Bozarth et al. (2009, p. 79) also refer to this dynamic aspect as "the unpredictability of a system's response to a given set of inputs, driven in part by the interconnectedness of the many parts that make up the system."

Maylor and Turner (2017) further developed these three dimensions and proposed a complexity response framework with three idealised response mechanisms. They posited that each of these complexities could be mitigated by a generalized set of responses to each challenge. First, a 'planning and control' approach (including standard management tools and techniques to manage improvement and change) could help mitigate structural challenges. Second, socio-political complexities are mitigated through 'relationshipdevelopment' with key stakeholders, focusing on information sharing to establish a more harmonious ecosystem. Third, emergent complexities are mitigated by enabling 'flexibility' and bringing expertise and judgement to bear on the specific problem at hand. The authors explored whether the three forms of complexity could be effectively addressed by each corresponding response mechanism. However, their results showed that managers' responses were not aligned as neatly as originally suggested, and that nine distinct complexity/response options emerged. This led to a $3 \times 3$ framework that can be used to classify the nature of the challenges (complexities) being faced, and the corresponding responses to mitigate them. The framework offers an insightful approach to framing and analysing the 'messy' (Ackoff, 1979) realities of an AM adoption process in a rigorous fashion.

Building on the work of Aitken et al. (2016) and Maylor and Turner (2017), Turner et al. (2018) applied the complexity response matrix in understanding the reactions of SME managers to situations they faced in their supply chain. To illustrate the applicability of the framework to a (generic) supply chain environment, they produced an example analysis to demonstrate the principles, shown in Table II. We use this general framework as the basis for our specific AM analysis, shown later. 
Table II. Components of clusters (adapted from Fraser and Kelly, 2010)

\begin{tabular}{|c|c|c|}
\hline $\begin{array}{l}\text { Success } \\
\text { Components }\end{array}$ & Description & References \\
\hline $\begin{array}{l}\text { Large pillar } \\
\text { firm presence }\end{array}$ & $\begin{array}{l}\text { Facilitates communication and collaboration as well as } \\
\text { providing support for start-ups and boosting credibility }\end{array}$ & $\begin{array}{l}\text { Chetty et al 2018; } \\
\text { Fraser and Kelly, } 2010\end{array}$ \\
\hline Local demand & $\begin{array}{l}\text { Can emerge due to a "window of locational opportunity" } \\
\text { created by exogenous triggers, reflecting the need for } \\
\text { demand to ensure cluster growth. }\end{array}$ & $\begin{array}{l}\text { Ingstrup et al., 2017; } \\
\text { Fornahl et al., } 2010\end{array}$ \\
\hline $\begin{array}{l}\text { Key } \\
\text { agents/Local } \\
\text { company } \\
\text { linkages }\end{array}$ & $\begin{array}{l}\text { Generally, from large pillar firms or education and research } \\
\text { institutes. Provide advice, consultation, education and } \\
\text { mentoring support as well as venture capital funds. Key } \\
\text { agents can act as intermediaries and knowledge brokers. }\end{array}$ & $\begin{array}{l}\text { Pan 2019; Smedlund, } \\
2006\end{array}$ \\
\hline $\begin{array}{l}\text { Regional } \\
\text { specialization }\end{array}$ & $\begin{array}{l}\text { Enables local/central government in identifying relevant } \\
\text { support to develop specialism and expertise for a region. } \\
\text { Creating and supporting specialist zones }\end{array}$ & $\begin{array}{l}\text { Vernay et al., 2018, } \\
2019\end{array}$ \\
\hline $\begin{array}{l}\text { Local } \\
\text { academic links }\end{array}$ & $\begin{array}{l}\text { Supporting the needs of local businesses through research } \\
\text { centres and specialist executive training courses }\end{array}$ & $\begin{array}{l}\text { Pan, 2019; Fraser and } \\
\text { Kelly, 2010 }\end{array}$ \\
\hline $\begin{array}{l}\text { Sophisticated } \\
\text { workforce }\end{array}$ & $\begin{array}{l}\text { Highly skilled labour important as a precondition for the } \\
\text { growth of innovative clusters. Specialized training required } \\
\text { through academic support }\end{array}$ & $\begin{array}{l}\text { Fornahl et al., 2010; } \\
\text { Bresnahan et al., } 2001\end{array}$ \\
\hline $\begin{array}{l}\text { Management } \\
\text { skills }\end{array}$ & $\begin{array}{l}\text { Lack of management and commercialization skills in small } \\
\text { enterprises can limit cluster development. Successful } \\
\text { clusters need to possess resources and skills that they can } \\
\text { use to strengthen their performance }\end{array}$ & $\begin{array}{l}\text { Colvic, 2019; Fraser } \\
\text { and Kelly, } 2010\end{array}$ \\
\hline Buzz & $\begin{array}{l}\text { Refers to the information and communication ecology } \\
\text { created by face-to-face contacts, co-presence and co- } \\
\text { location of people and firms within the same industry and } \\
\text { place or region. Buzz is spontaneous, dynamic and can } \\
\text { rapidly diffuse knowledge and information through a local } \\
\text { cluster. }\end{array}$ & $\begin{array}{l}\text { Bathelt et al., 2004; } \\
\text { Fraser and Kelly, } 2010\end{array}$ \\
\hline Pipelines & $\begin{array}{l}\text { The act of building channels of communication to selected } \\
\text { agents outside of the cluster to build knowledge. These } \\
\text { pipelines which can bring knowledge to the cluster can be } \\
\text { local, regional, national or global. }\end{array}$ & Fraser and Kelly, 2010 \\
\hline
\end{tabular}

For the AM cluster, structural complexity challenges could arise as the product range and capacity to meet the urgent needs of healthcare customers are expanded. The planning of resources and growth in the number of actors (suppliers and customers) could elevate the levels of structural complexity. Sociopolitical complexity may increase as actors align their processes and procedures to realize the opportunity provided by the supply chain disruption to PPE. Collaboration to develop shared objectives and alignment of information flows across loosely coupled actors could be problematic for the cluster. Finally, emergent complexity may arise as demand uncertainty for new products, coupled with a lack of technical knowledge 
on the standards of the healthcare sector could lead to pressure on change, capacity and risk management. The framework above was employed as the basis for analysis and classification of the events that transpired within our AM cluster case study, enabling a clearer understanding and classification of both the unique complexities faced by managers in this instance, and the associated responses adopted by different managers as they addressed the dual challenge of PPE shortages and rapid surge in localized demand for PPE.

\subsection{Method}

The purpose of this longitudinal study was to examine the formation and development of an Australian geographic cluster which responded to a supply crisis through the application of AM. The AM cluster is relatively small in size and located in a region where there are three larger organizations - including a hospital, university and steel manufacturer. Due to changes in the economic environment, however (particularly for the declining steel manufacturer), technology start-ups and SMEs have become even more important to preserve and encourage innovative businesses to rejuvenate the region. This regional initiative was underpinned by the establishment of knowledge centers and innovation hubs to support and train local workforces. The local University initiated the emergence of the cluster, due to its significant presence in the region as a recognized provider of advanced technical and managerial skills and education in the business community (Fraser and Kelly, 2010). The formation of technology clusters, as a vehicle for encouraging new business ecosystems, was already set in motion as part of the regional development efforts in the area. Interest in the importance of localized clusters and their impact on innovation and entrepreneurship is evident in the literature for multiple countries and regions, such as those in Spain, USA, and The Netherlands (Albert, 2017; Friar and Meyer, 2003; Gries and Naude, 2009; Koster, van Stel and Folkeringa, 2012). Such was also the case in Australia, where the formation of the cluster was already set in motion in 2019 through a government grant focusing on AM teaching and education to enable knowledge spill-over in the local manufacturing industry. Many of the components required to develop a cluster were significantly influenced by the arrival of the pandemic, which had a transformational effect on growth. The four cluster entities we studied prior and during the early stages of Covid-19 were all within a $25 \mathrm{~km}$ radius from one other. Table III provides an overview of the four AM cluster members including their market focus, AM capabilities and their unique value proposition towards the cluster.

Table III. Overview of key AM cluster entities

\begin{tabular}{|l|l|l|l|l|}
\hline$\#$ & Network Actors & Market Focus & AM capabilities & $\begin{array}{l}\text { Unique Cluster } \\
\text { Value Proposition }\end{array}$ \\
\hline $\mathbf{1}$ & $\begin{array}{l}\text { EDUCATE (SME) } \\
\text { Commercial provider of 3D } \\
\text { printers, software including } \\
\text { operating systems and } \\
\text { educational packages. }\end{array}$ & $\begin{array}{l}\text { Schools and other } \\
\text { education } \\
\text { providers. }\end{array}$ & $\begin{array}{l}\text { Printers for schools } \\
\text { Cloud-based } \\
\text { operating system. }\end{array}$ & $\begin{array}{l}\text { Cloud based } \\
\text { operating system } \\
\text { allows cluster AM } \\
\text { printer network } \\
\text { coordination. }\end{array}$ \\
\hline $\mathbf{2}$ & PRINT- BUREAU (SME) & $\begin{array}{l}\text { Australian and New } \\
\text { Zealand }\end{array}$ & $\begin{array}{l}\text { Some AM design } \\
\text { and hardware, }\end{array}$ & $\begin{array}{l}\text { Website brings in } \\
\text { clients for AM }\end{array}$ \\
\hline
\end{tabular}




\begin{tabular}{|l|l|l|l|l|}
\hline & $\begin{array}{l}\text { Commercial printing } \\
\text { bureau. }\end{array}$ & $\begin{array}{l}\text { commercial and } \\
\text { private customer. }\end{array}$ & $\begin{array}{l}\text { predominantly AM } \\
\text { printing services. }\end{array}$ & $\begin{array}{l}\text { cluster ([1] and [3] } \\
\text { provide capability } \\
\text { and capacity } \\
\text { buffer). }\end{array}$ \\
\hline $\mathbf{3}$ & $\begin{array}{l}\text { UNI R\&D } \\
\text { Institute as part of a } \\
\text { tertiary education provider. }\end{array}$ & $\begin{array}{l}\text { Healthcare } \\
\text { industry, clinical } \\
\text { networks. }\end{array}$ & $\begin{array}{l}\text { Design, bioprinter } \\
\text { development and } \\
\text { manufacturing, } \\
\text { R\&D provider to } \\
\text { local industry. }\end{array}$ & $\begin{array}{l}\text { Capability buffer } \\
\text { (wider range of } \\
\text { printers); extensive } \\
\text { R\&D AM know- } \\
\text { how. }\end{array}$ \\
\hline $\mathbf{4}$ & $\begin{array}{l}\text { MAKER SPACE } \\
\text { A makerspace that is part } \\
\text { of an innovation precinct } \\
\text { that belongs to a tertiary } \\
\text { education provider (same } \\
\text { as [3]). }\end{array}$ & $\begin{array}{l}\text { Local public with a } \\
\text { strong focus on } \\
\text { STEM education in } \\
\text { partnership with } \\
\text { schools and } \\
\text { university students. }\end{array}$ & $\begin{array}{l}\text { Hardware provider } \\
\text { of basic AM } \\
\text { equipment for } \\
\text { hobbyist, tinkerers } \\
\text { and pupils/ } \\
\text { students. }\end{array}$ & $\begin{array}{l}\text { Community } \\
\text { outreach, } \\
\text { developing the } \\
\text { next generation } \\
\text { makers, Buzz } \\
\text { creator. }\end{array}$ \\
\hline
\end{tabular}

This research relied on a single in-depth longitudinal case study of the four firms, to explore the formation of the cluster over an eight-month period. Initially, we sought to identify the key attributes of AM clusters in general, however the sudden development of localized demand, through the Covid-19 pandemic PPE supply issues, altered the focus of the team in February 2020. The exogeneous supply chain shock proffered the opportunity to see how the AM cluster responded to a sudden disruption in supply. In this context, we sought to understand how the presence of uncertain demand and enormous shortages in PPE would predicate changes in the response of cluster participants, with a goal of gaining an in-depth understanding of this particular situation, rather than a broad view or study of relationships between a series of cases. Limitations on our approach include generalizability, as only one case study is used (Steinburg, 2015; Voss, Tsikriktsis and Frolich, 2000). However, a strength of this research is that the single case of the AM cluster provided a unique in-depth exploration of how AM clusters can respond to unexpected disasters such as Covid-19 (Voss et al., 2000). Australia, like many other countries, was hit with massive PPE shortages, as supplies of N95 face masks, gowns, and gloves became scarce with China limiting exports during the early days of the crisis, and international demand for these products exploded as the virus spread to Europe, the US, and Latin America.

According to Yin (2014, p. 16), case studies allow for the in-depth investigation of a "contemporary phenomenon.... within its real-world context". Case studies are said not only to support the development and explication of theory, but also support the aims of those performing the research (Voss et al., 2000). Researchers can immerse themselves in the case and explore the reasons for/causality of certain phenomena and the environment for example, rather than just the results (McCutcheon and Meredith, 1993). We also took steps to minimize the "guinea pig effect", or awareness of being tested, through indirect discussions and observation over the course of the study (Webb et al., 1966).

Data collection for the case study took place over an eight month period from late 2019 till mid-2020. Key senior staff from all four entities were engaged during this period. Contact with the AM cluster occurred 
at regular intervals throughout the data collection process, (for example by email in between interviews), to keep up to date with the development process. This reduced distraction and awareness of the participants while they were being observed by the researchers during the cluster formation period, particularly for minor questions. Several different interview targets were used to incorporate different perspectives from within the cluster. Senior managers from all four entities were interviewed as well as key internal personnel managing in-house processes and interfaces with cluster members. Observations of operations were conducted in the different facilities. This allowed the researchers to observe and create flow charts and value stream maps. In total, 18 staff members participated in this longitudinal study and were interviewed at different points in time. Interviews ranged from approximately one hour at the beginning of the study to 30 minutes towards the end of the study, with research targeting a variety of employees including (senior) management as well as technicians. Semi-structured interviews were conducted both individually and in groups on-site, as well as by phone to individuals, to capture further data and verify findings. Table IV provides an overview of the timeframe, the activities and the data collected.

Table IV Research overview including timeframe, activities and data sources

\begin{tabular}{|c|c|c|}
\hline Timeframe & Activity & Data Collection \\
\hline $\begin{array}{l}01.10 .2019- \\
28.02 .2020 \\
\text { 'Pre-Disruption' }\end{array}$ & $\begin{array}{l}\text { Cluster Formation } \\
\text { - Company Site visits } \\
\text { with each cluster } \\
\text { member ( } 3 \text { hrs each) } \\
\text { - } \text { AM workshop hosted } \\
\text { by UNI R\&D (full day) } \\
\text { - Contract between UNI } \\
\text { R\&D and PRINTING } \\
\text { BUREAU ( } 2 \text { hrs) }\end{array}$ & $\begin{array}{l}\text { - Observations } \\
\circ \quad \text { Shop Floor } \\
\circ \text { Office Space } \\
\text { - Value Stream Mapping } \\
\circ \quad \text { On-site value stream mapping from } \\
\text { customer interface to procurement } \\
\text { - Interviews } \\
\circ \text { Managing Directors (2x) } \\
\circ \text { Team Leaders (4X) } \\
\circ \text { Operations Manager (3x) } \\
\circ \text { Marketing Manager (4x) } \\
\circ \text { Technicians (4x) } \\
\circ \text { Quality Manager (1x) } \\
\text { E-mail correspondence (clarification) }\end{array}$ \\
\hline $\begin{array}{l}01.03 .2020- \\
31.03 .2020 \\
\text { 'Covid' }\end{array}$ & $\begin{array}{l}\text { Cluster Growth } \\
\text { - } \text { PPE demand } \\
\text { recognition } \\
\text { - } \text { PPE shield design } \\
\text { - } \text { PPE AM } \\
\text { - } \text { PPE dispatch }\end{array}$ & 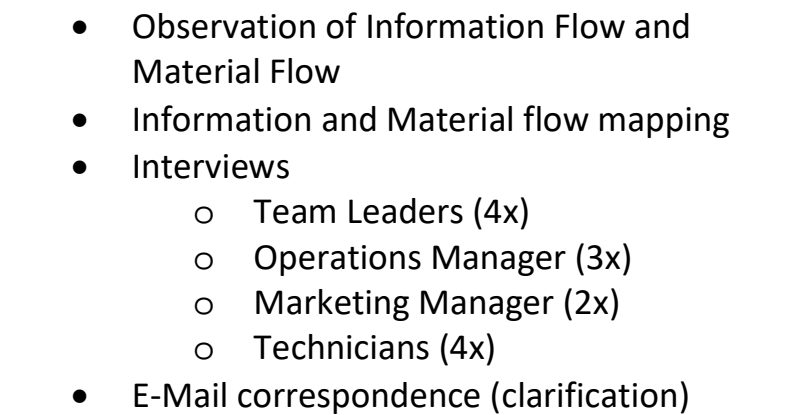 \\
\hline $\begin{array}{l}\text { 01.04.2020 - } \\
31.05 .2020 \\
\text { 'Post (major) } \\
\text { Disruption' }\end{array}$ & $\begin{array}{l}\text { Cluster Sustaining } \\
\bullet \quad \text { Workshop on } \\
\text { sustaining buzz }\end{array}$ & $\begin{array}{l}\text { - Online company workshop and discussion } \\
\text { group } \\
\text { - Individual Interviews } \\
\circ \text { Managing Directors (2x) } \\
\circ \text { Team Leaders (4X) }\end{array}$ \\
\hline
\end{tabular}




\subsection{Findings}

\subsection{Cluster Formation (pre-supply chain disruption)}

Prior to the supply chain disruption caused by the Covid-19 pandemic the cluster could be best described as a loosely coupled group of independent organizations pioneering and aligned by a common interest in AM technology. The company EDUCATE was co-founded by a staff member of UNI-R\&D in order to provide educational printers for schools and alternative education providers. UNI-R\&D in return used some of the EDUCATE printer designs as a platform for the development of their in-house bio-printers. However, commercial activities were kept to a minimum with no clearly identified commercial projects. PRINTBUREAU had more commercial interaction with UNI-R\&D and would pass on some commercial jobs if they did not have the capability or capacity in-house, providing a platform for planning and organizing resources. Likewise, clients that wanted to obtain quotes for commercial jobs from UNI-R\&D were directed to PRINT-BUREAU if they could match capability and capacity, therefore underpinning the value of the dyadic exchange and minimizing the risk of losing the relationship and future business with clients. PRINT-BUREAU and UNI-R\&D would mainly compete on R\&D projects with industry partners. MAKERSPACE was the latest addition to the AM cluster. This organization, owned and operated by a local tertiary education provider, was tasked with public engagement and providing access and education to enthusiasts, 'tinkerers', as well as pupils and students. MAKER-SPACE has a natural collaboration with UNIR\&D since both belong to the same tertiary education provider, facilitating the flow of information.

UNI-R\&D in collaboration with MAKER-SPACE conducted an AM cluster network meeting, to develop relationships and informal communications amongst the participants, prior to the supply chain disruption caused by the Covid-19 outbreak. UNI-R\&D acted as a champion to foster a stronger collaboration amongst cluster members, as well as introducing local innovative manufacturers to the network, therefore increasing the overall flexibility and capacity. The manager of UNI-R\&D stated:

"We need to have more relevance to our local manufacturing industry and create meaningful engagement and knowledge spill-over opportunities to advance our local manufacturing capabilities."

The cluster up to this stage had focused on developing knowledge and promoting the potential of the technology. However, it was recognized by UNI-R\&D that there was an emerging need for formalization through agreement on governance, information movement, and controls. Roles, objectives and ways of operating were openly discussed and implemented to improve coordination of resources and the flow of information across boundaries. For example, PRINT-BUREAU operated two websites to channel 3D printing demand to their business. UNI-R\&D provided PRINT-BUREAU with a much wider offering due to alternate printing techniques and materials such as metal printing. Companies introduced to the cluster will work with UNI-R\&D in the first instance for prototype development prior to engaging with PRINTBUREAU for small batch production. Despite these discussions, the AM cluster was still loosely coupled in its operation with limited activities outside of knowledge-building and capacity-sharing. Developments around market and sales opportunities for the cluster were limited. Figure 1 provides a network diagram 
highlighting the cluster interactions. A solid line indicates mature commercial relationship, a dotted line highlights loose, non-commercial relationship

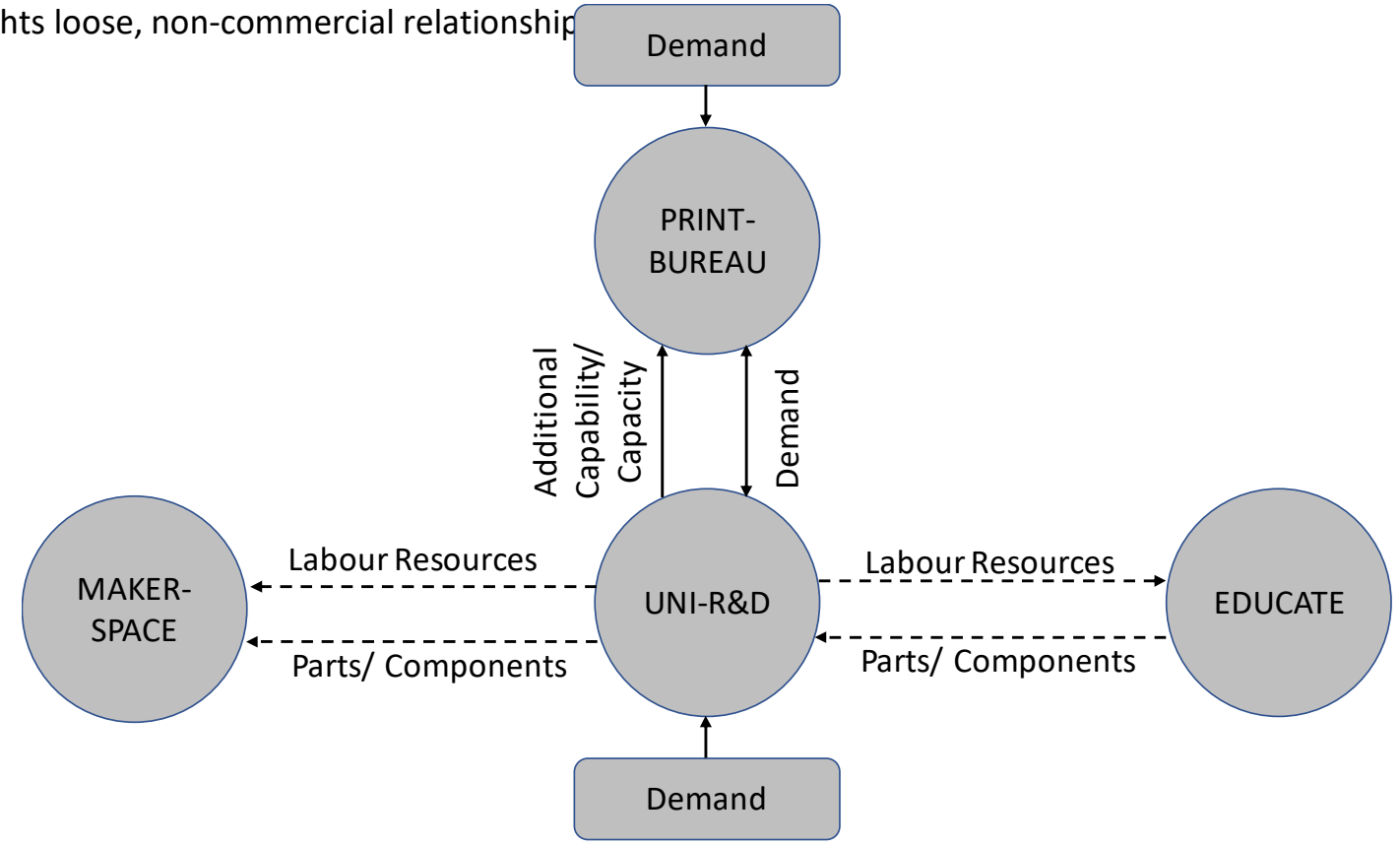

Figure 1: Network diagram of cluster interactions pre-supply chain disruption.

The pre-supply chain disruption cluster activities have been mapped onto the complexity framework for analysis. Table $\mathrm{V}$ provides an overview of cluster activities

Table V. Cluster formation (prior to supply chain disruption) activities

\begin{tabular}{|c|c|c|c|}
\hline $\begin{array}{l}\text { Complexity } \rightarrow \\
\text { Response }\end{array}$ & Structural & Socio-political & Emergent \\
\hline Planning and Control & $\begin{array}{l}\text { UNI-R\&D as coordinator } \\
\text { in controlled, unbiased, } \\
\text { environment, acting as } \\
\text { knowledge hub and } \\
\text { coordinator of cluster } \\
\text { resources. }\end{array}$ & $\begin{array}{l}\text { Contract in place to make } \\
\text { UNI-R\&D a subcontractor } \\
\text { for PRINT-BUREAU, } \\
\text { clarifies and legalizes } \\
\text { positions of partners. This } \\
\text { Provides the basis for } \\
\text { communications between } \\
\text { members. }\end{array}$ & $\begin{array}{l}\text { Informal planning and } \\
\text { control of commercial } \\
\text { jobs. The lack of } \\
\text { governance and } \\
\text { structure to manage } \\
\text { contended issues is } \\
\text { becoming an obstacle } \\
\text { and risk to future } \\
\text { growth. }\end{array}$ \\
\hline $\begin{array}{l}\text { Relationship- } \\
\text { development }\end{array}$ & $\begin{array}{l}\text { UNI-R\&D in collaboration } \\
\text { with MAKER-SPACE } \\
\text { conducts an AM cluster } \\
\text { network meeting, to }\end{array}$ & $\begin{array}{l}\text { All cluster members but } \\
\text { PRINT-BUREAU have a } \\
\text { formal affiliation with } \\
\text { UNI-R\&D, facilitating } \\
\text { information flows. }\end{array}$ & $\begin{array}{l}\text { Concerns over R\&D } \\
\text { work and who } \\
\text { benefits - } \\
\text { transparency required } \\
\text { to keep participants }\end{array}$ \\
\hline
\end{tabular}




\begin{tabular}{|l|l|l|l|}
\hline & $\begin{array}{l}\text { develop relationships } \\
\text { amongst the members. }\end{array}$ & $\begin{array}{l}\text { Informal relationships } \\
\text { exist, but not } \\
\text { commercially explored. }\end{array}$ & $\begin{array}{l}\text { engaged in the } \\
\text { cluster. Network } \\
\text { meetings used to } \\
\text { enhance informal } \\
\text { communications } \\
\text { however, this is not } \\
\text { sufficient in itself. }\end{array}$ \\
\hline Flexibility & $\begin{array}{l}\text { PRINT-BUREAU operates } \\
\text { two websites to channel } \\
\text { 3D printing demand to } \\
\text { their business providing } \\
\text { flexibility through IT. }\end{array}$ & $\begin{array}{l}\text { UNI-R\&D acts as a } \\
\text { sponsor to champion and } \\
\text { foster a stronger } \\
\text { collaboration amongst } \\
\text { cluster members, as well } \\
\text { as introducing local } \\
\text { innovative manufacturers } \\
\text { to the network, therefore } \\
\text { increasing the overall } \\
\text { flexibility and capacity . }\end{array}$ & $\begin{array}{l}\text { Belief within cluster } \\
\text { that AM will change } \\
\text { the way we } \\
\text { manufacture in the } \\
\text { future (pre-Covid) } \\
\text { through its agility. }\end{array}$ \\
\hline
\end{tabular}

The large pillar organization in the informal cluster was UNI-R\&D which acted as a sponsor and developer of company linkages as well as being a knowledge holder and resource coordinator. Common amongst informal cluster members was the overarching belief that AM's agility would disrupt existing manufacturing and provide new opportunities. The manager of PRINT-BUREAU pointed out:

"The cluster views 3D printing as a technology which could open up new business opportunities in a steadily declining industry. Traditional manufacturing has many constraints, is slow to enact and very expensive when compared to South East Asia. This new technology has the potential to become a game changer for re-shoring some of our lost manufacturing capability using process and design flexibility and versatility. The constraints of old manufacturing approaches and thinking were not limiting the possibilities that 3D printing could deliver."

The structural elements in forming the cluster were based on informal relationship ties. In these early stages the initial relationship-based way of working was effective and slowly becoming formalized and regulated through official affiliations and contracts. The development of structure was needed to improve visibility of value flow, address evolving concerns over R\&D benefit sharing, and reduce perceived commercial risk. At this stage the purpose of the cluster had been to share and develop knowledge. However, as this value grew, tensions were becoming apparent. The lack of governance and structure to manage contended issues was becoming an obstacle and risk to future growth. The CEO of EDUCATE made the following statement:

"We recognized that the lack of governance and structure within the cluster was creating tension and issues for our group. Developing and sharing knowledge is fine. However, without an 
agreement on roles and direction we would not be able to move forward. Particularly on the commercial aspects."

The cluster before the pandemic had begun to shift from a loosely coordinated knowledge sharing and relationship building mode to a more formalized structure. Increased planning and control measures were instigated to capitalize on the capacity and resources of the cluster. These changes necessitated the development of a governance model, by the sponsor organization, to support information flows and address emerging commercial risk concerns.

\subsection{Cluster Development (during supply chain disruption)}

The supply chain disruption caused by the Covid-19 pandemic resulted in a rapid re-prioritization of the AM cluster to address PPE needs in regional Australia. UNI-R\&D and MAKER-SPACE were simultaneously approached in March 2020 by their clinical networks to develop a protective face-shield design to protect frontline clinical staff. Overseas supply had ceased due to a surge in global demand and the impact of the virus on production. UNI-R\&D took on the role of value network leader and coordinator as well as supporting R\&D development including fast-track governmental approval for the design to be adopted by healthcare providers. Planning and control was organized by UNI-R\&D as it operated as the main contractor of the three other cluster members. UNI-R\&D coordinated work and kept participants on board by giving them paid work, therefore reducing potential organizational boundary issues.

The face-shield is made of three components: a 3D printed head-ring, a rubber band, and a soft plexiglass shield (see Figure 2). The demand for face-shields required input from all cluster members and a cluster manufacturing process had to be established. EDUCATE developed a unique, in-house, cloud-based operating system, and managed to activate many of their in-house printers in close proximity to help with the printing of head-rings using this system. PRINT-BUREAU also supported the 3D printing of head-rings. EDUCATE has further improved on PPE product design and received approval from the government for future commercial sales. UNI-R\&D activated their in-house printer network and managed the product change processes for the cluster through conducting the final assembly, sterilization, packaging and shipment of final product to end-users. The rapid increase in local demand combined with an overarching purpose that was beyond the interest of each unit individually resulted in a 'buzz' that allowed the tightening of the AM cluster and a collaborative mindset. The manager of the MAKER SPACE commented:

"The supply disruption to PPE provided a real fillip to the cluster in terms of meeting a major societal challenge as well as business opportunity. This gave us real and immediate purpose to our collaboration beyond our belief that AM will eventually change the way we manufacture in Australia." 


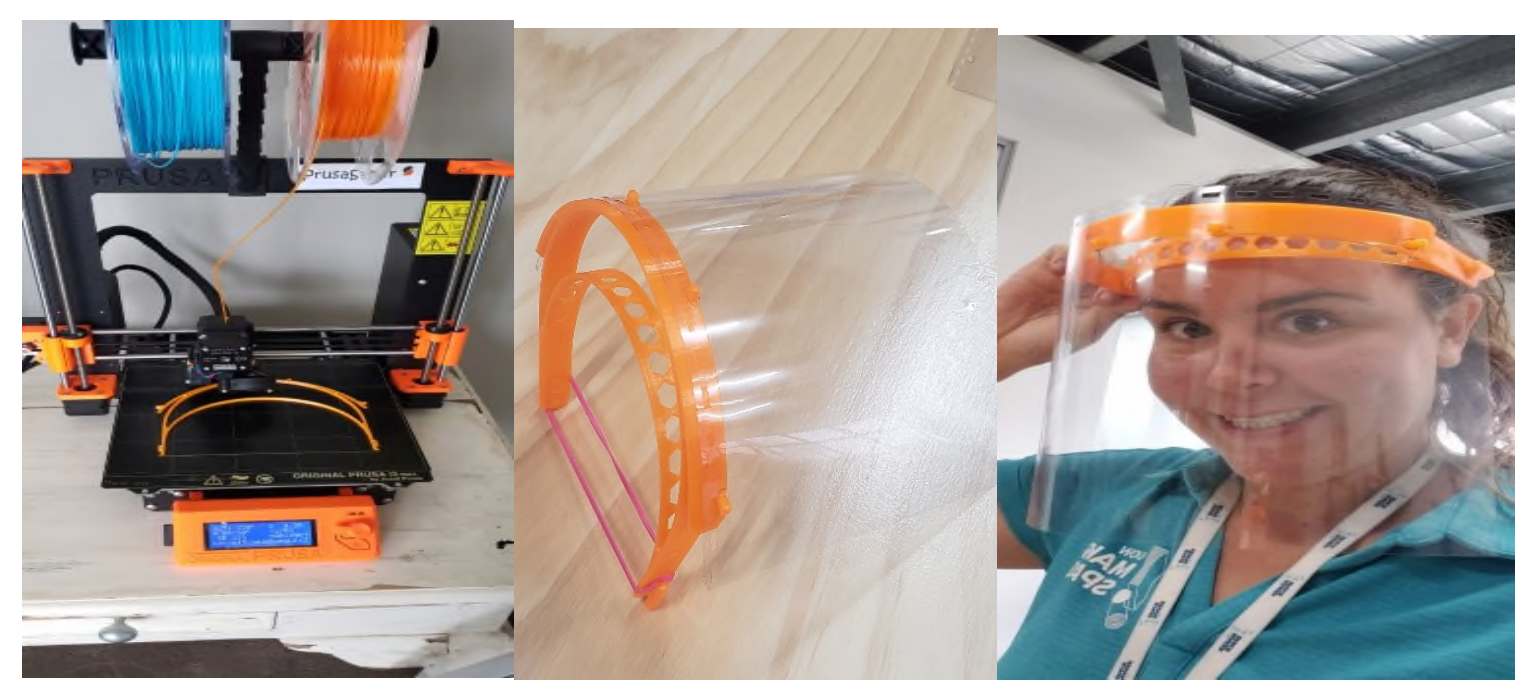

Figure 2: 3D printed head-ring, a rubber band, and a soft plexiglass shield

Local newspapers frequently reported on cluster activities, and UNI-R\&D broadcasted updates on common social media platforms creating a buzz in the local community. The buzz resulted in a significant increase in requests by the local 3D printing 'tinkerer' community that offered their services to tackle the health crisis and support frontline healthcare workers. The tinkerer community consisted primarily of local hobbyists operating low-cost printers, and 3D printing knowledge was predominantly self-taught. MAKERSPACE coordinated community support and resources by sharing designs and providing technical assistance. The newly operating cluster, including the tinkerer community, managed to respond to demands within two days of the first prototypes being developed. Proximity allowed the surge in demand to be accommodated as quick information flows underpinned collaboration and problem solving. Figure 3 provides a network diagram of the extended collaboration among AM network partners and their interactions for the manufacture of PPE products. 


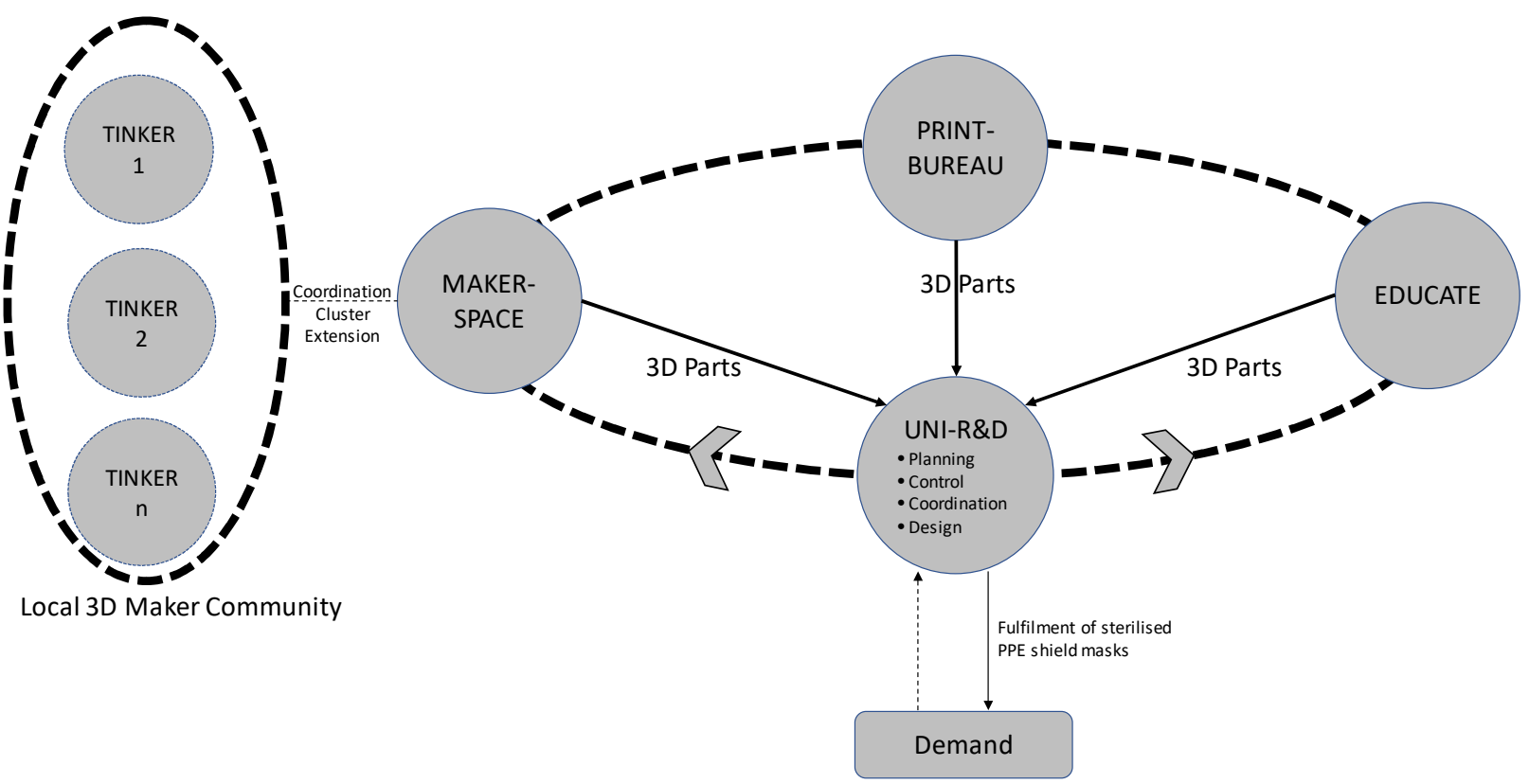

Figure 3: Network diagram during cluster development

The development of the cluster due to the supply chain disruption activities was mapped onto the supply chain complexity framework for further analysis. Table VI provides an overview of cluster supply chain disruption activities.

Table VI Cluster development

\begin{tabular}{|c|c|c|c|}
\hline $\begin{array}{l}\text { Complexity } \rightarrow \\
\text { Response }\end{array}$ & Structural & Socio-political & Emergent \\
\hline $\begin{array}{l}\text { Planning and } \\
\text { Control }\end{array}$ & $\begin{array}{l}\text { Planning and Control } \\
\text { conducted by UNI-R\&D } \\
\text { as coordinator and main } \\
\text { contractor of the } 3 \\
\text { subcontractors. MAKER- } \\
\text { SPACE coordinates the } \\
\text { community tinkerer } \\
\text { network and resource. } \\
\text { Final assembly, } \\
\text { sterilization and } \\
\text { dispatch at UNI-R\&D. }\end{array}$ & $\begin{array}{l}\text { UNI-R\&D coordinates work } \\
\text { and keeps participants on } \\
\text { board by giving work that } \\
\text { the cluster would be paid } \\
\text { for. This approach reduces } \\
\text { potential organizational } \\
\text { boundary issues amongst } \\
\text { actors. }\end{array}$ & $\begin{array}{l}\text { UNI-R\&D acts as the main } \\
\text { interface with end-user } \\
\text { (healthcare and clinicians' } \\
\text { network). However, the } \\
\text { underlying R\&D benefit } \\
\text { sharing and commercial } \\
\text { arrangements for the } \\
\text { cluster are still a risk } \\
\text { management issue. } \\
\text { EDUCATE has further } \\
\text { improved on PPE product }\end{array}$ \\
\hline
\end{tabular}




\begin{tabular}{|l|l|l|l|}
\hline & & & $\begin{array}{l}\text { design and received } \\
\text { approval by the } \\
\text { government for future } \\
\text { commercial sales. } \\
\text { UNI-R\&D activate their in- } \\
\text { house printer network and } \\
\text { manage the product } \\
\text { change processes. }\end{array}$ \\
\hline $\begin{array}{l}\text { Relationship- } \\
\text { development }\end{array}$ & $\begin{array}{l}\text { Proximity enables easy } \\
\text { communication. All four } \\
\text { entities stay open even } \\
\text { during lockdown. } \\
\text { Relationship building } \\
\text { takes place over 3-wk } \\
\text { intense period. }\end{array}$ & $\begin{array}{l}\text { Proximity allows the surge } \\
\text { in demand to be } \\
\text { accommodated as quick } \\
\text { information flows underpin } \\
\text { collaboration and problem- } \\
\text { solving. }\end{array}$ & $\begin{array}{l}\text { Shared experience of the } \\
\text { extreme consequences of } \\
\text { Covid and the ability to } \\
\text { make a difference with AM } \\
\text { enable problems to be } \\
\text { discussed and solved } \\
\text { rapidly through both } \\
\text { formal procedures and } \\
\text { informal communications. }\end{array}$ \\
\hline Flexibility & $\begin{array}{l}\text { All cluster participants } \\
\text { solve problems - } \\
\text { urgency and } \\
\text { improvement in IT links } \\
\text { enable them to join up } \\
\text { printers and } \\
\text { manufacture as fast as } \\
\text { possible. }\end{array}$ & $\begin{array}{l}\text { The newly operating } \\
\text { cluster, including the } \\
\text { tinkerer community, } \\
\text { manages to respond to } \\
\text { demands within two days } \\
\text { of the first prototypes } \\
\text { being developed. }\end{array}$ & $\begin{array}{l}\text { Themonstrated by UNI-R\&D } \\
\text { issuing a contract out to } \\
\text { cluster members within } \\
\text { hours, rather than months. } \\
\text { Design to dispatch of first } \\
\text { product is 2 days. }\end{array}$ \\
\hline
\end{tabular}

The rapid increase in demand and a desire to support local health care saw the loosely coupled cluster tightening. In the first instance, structural and contractual aspects were tackled in order to enhance flexibility to be able to respond to uncertain demand and support the agile approach that was being taken. This was followed by planning and control enhancements to coordinate cluster outputs. It also saw the large pillar organization, UNI-R\&D, emerge as the cluster champion for this project. Once structure and coordination were established, relationship development continued over a three-week intensive period. All cluster participants solved problems - urgency and improvement in IT links enabled them to join up printers and manufacture as fast as possible. Shared experience of the extreme consequences of Covid and the ability to make a difference with AM enabled problems to be discussed and solved rapidly through both formal procedures and informal communications. These steps began to address the emergent issues highlighted in the pre-supply chain disruption stage. However, it did not resolve the concerns and perceived risks around R\&D benefits or on-going commercial arrangements outside of supplying PPE equipment. The manager of UNI R\&D highlighted:

"During our response to the PPE shortage we put our concerns on the way the cluster operated to one side. We all wanted to focus on helping our healthcare workers. On reflection this crisis period helped us to understand some of the potential of the cluster but we should have also taken the opportunity to resolve our other issues and conducted some forward planning." 
The arrival of Covid-19 facilitated the quick expansion of the cluster, its customer base and technology use. Through improvements in IT links the cluster was able to share printers quickly and easily. The buzz that was generated, in response to the PPE supply chain crisis, enabled the organizations to solve problems quickly, increase output, and involve the wider tinkerer community. The sponsor organization addressed socio-political and structural issues through coordinating work and cash flows to allow the other cluster members time to focus on production.

\subsection{Post (major) supply chain disruption}

Data collection extended beyond the major supply chain disruption challenges caused by the Covid-19 crisis to capture network members' understanding of the next phase of this emerging cluster. The pandemic was still a significant factor within participants' lives, but the major reconfiguration that the cluster underwent was deemed to have stabilized. Interviews with cluster members established that it was the intention of all organizations to maintain the newly formed collaborative relationships. The pandemic highlighted the synergies of network participants and the ability to respond quickly not only to changes in demand but to develop, make, and supply novel solutions to emerging problems. It was pointed out by several network members that the existing demand for facial shields was not sustainable, and the traditional lean overseas supply chain would eventually replace the local agile cluster supply network. The manager of the PRINT-BUREAU reflected:

"Before the PPE crisis the cluster was not working well together, even so everyone knew of each other. We are all strong believers in the technology. That unites us and we are certain that eventually doors will open. The crisis has crystalized this and made us eager to develop more opportunities. We need to develop more commercial activities to make it pay for us all."

However, cluster members have explored opportunities to stimulate an increase in demand going forward through a network-wide adoption of the cloud-based operating system from EDUCATE. Figure 4 provides a network overview of the desired cluster interactions.

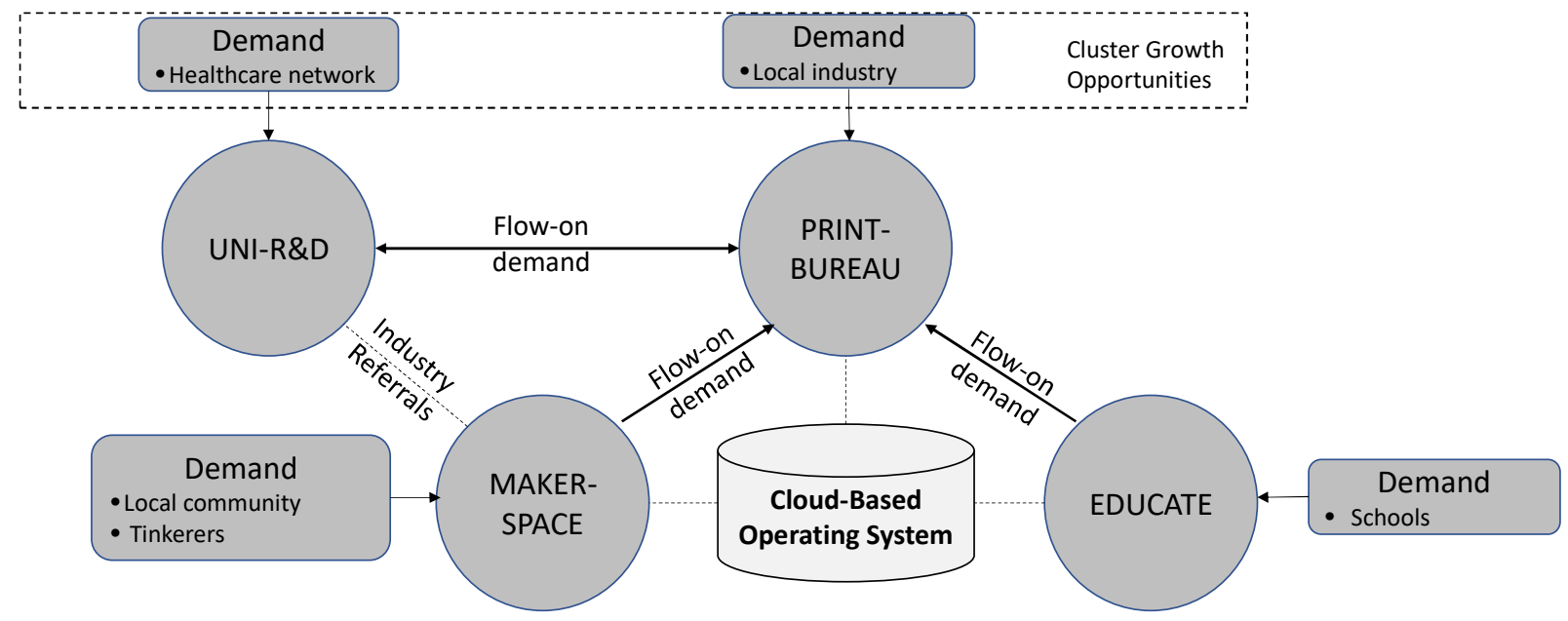

Figure 4: Cluster Network Post supply chain disruption 
It is not envisaged that UNI-R\&D will maintain the strong coordination and champion position in the cluster. The cluster members' demand for support and coordination elevated it into this position during the peak of the pandemic. However, computer-based coordination enhancements enable the natural progression of the cluster without the pivotal broker linking role of UNI-R\&D. PRINT-BUREAU and MAKERSPACE are aiming to implement the cloud-based operating system that was developed by EDUCATE for a licensing fee, increasing the flexibility and capacity of the cluster. This would allow the cluster members to seamlessly integrate their 3D printing capability and capacities onto a single platform. Users such as school pupils working on 3D printers supplied by EDUCATE or students and tinkerers from the local society working with MAKER-SPACE would be able to tap into the commercial printers of the PRINT-BUREAU paying a fee for service once their designs are finalised. By maintaining and developing the societal bonds that were strengthened during the pandemic, UNI-R\&D continues to provide buffer capacity and additional capability such as metal printers if desired. MAKER-SPACE also works with local industry partners including activities such as maker workshops. UNI-R\&D aims to work more closely with MAKERSPACE to provide advanced research and development services and specialist training if demanded.

It was clearly pointed out during the interviews that it is necessary to sustain the 3D printing buzz that was created during the Covid-19 pandemic. Informal relationship management and coordination will include all four members including the growing manufacturing and healthcare networks. UNI-R\&D will be key in the facilitation of those relational activities through offering workshops to explore new offerings with existing products, while continuing the developing of dialogue between participants. The movement from a cluster focused on sharing and creating knowledge of AM to a network that commercializes its potential was viewed as essential in developing and expanding the group. Providing education on the commercial and management skills required to realize the opportunity that AM can deliver was viewed as a critical aspect of the relational development for UNI-R\&D. The manager of EDUCATE concluded the Covid-19 activities as follows:

"The cluster has come to realize the potential of AM to transform manufacturing and deliver value in a quick and flexible way. The next important stage is the reinforcement and development of commercial and managerial skills of the cluster members to help grow the market opportunities that PPE shortage highlighted."

The success of the cluster outputs resulted in an increase of media coverage and envy by some cluster participants of the over-representation of an individual cluster member. Regular informal meetings were held to maintain healthy cluster relationships, manage emerging tensions and develop ongoing opportunities. On-boarding of new manufacturing organizations that would complement and strengthen the cluster was viewed as important to broaden the technical and commercial opportunities of the cluster. Existing cluster members can reject new members, this limits unnecessary tension within the group and minimizes risk. MAKER-SPACE will continue developing the tinkerer community to sustain engagement, drive cluster demand and provide capacity flexibility. Network members emphasized the point that the desired state of the network as depicted in Figure 4 will only come to fruition if each has a clear understanding of their role and responsibilities in the network. Table VII provides an overview of anticipated future cluster development activities. 
Table VII Post supply chain disruption development activities

\begin{tabular}{|c|c|c|c|}
\hline $\begin{array}{l}\text { Complexity } \rightarrow \\
\text { Response }\end{array}$ & Structural & Socio-political & Emergent \\
\hline $\begin{array}{l}\text { Planning and } \\
\text { Control }\end{array}$ & $\begin{array}{l}\text { PRINT-BUREAU and } \\
\text { MAKER-SPACE aim to } \\
\text { implement the cloud- } \\
\text { based operating } \\
\text { system that was } \\
\text { developed by } \\
\text { EDUCATE for a } \\
\text { licensing fee. This } \\
\text { would allow the three } \\
\text { cluster members to } \\
\text { seamlessly integrate } \\
\text { their 3D printing } \\
\text { capability and } \\
\text { capacities onto a single } \\
\text { platform. }\end{array}$ & $\begin{array}{l}\text { Plans developed to on- } \\
\text { boarding new cluster } \\
\text { actors, to ensure } \\
\text { complementarity and } \\
\text { diminish potential } \\
\text { organizational boundary } \\
\text { issues, is viewed as } \\
\text { important. }\end{array}$ & $\begin{array}{l}\text { Existing cluster members } \\
\text { can reject new members, } \\
\text { this limits unnecessary } \\
\text { tension within the group } \\
\text { and minimizes risk. }\end{array}$ \\
\hline $\begin{array}{l}\text { Relationship- } \\
\text { development }\end{array}$ & $\begin{array}{l}\text { Supplier management } \\
\text { through repeating the } \\
\text { workshop } \\
\text { ('onboarding process') } \\
\text { for new participants to } \\
\text { bring them into the } \\
\text { cluster. }\end{array}$ & $\begin{array}{l}\text { Regular informal meetings } \\
\text { held to maintain } \\
\text { transparency, align } \\
\text { objectives, and generate } \\
\text { cluster ideas. }\end{array}$ & $\begin{array}{l}\text { The next important stage is } \\
\text { the reinforcement and } \\
\text { development of } \\
\text { commercial and } \\
\text { managerial skills of the } \\
\text { cluster members to help } \\
\text { grow the market } \\
\text { opportunities that PPE } \\
\text { shortage highlighted. UNI- } \\
\text { R\&D facilitates this with } \\
\text { workshops to explore new } \\
\text { offerings with existing } \\
\text { products, while developing } \\
\text { communications between } \\
\text { participants. }\end{array}$ \\
\hline Flexibility & $\begin{array}{l}\text { Cluster members } \\
\text { explore opportunities } \\
\text { to stimulate an } \\
\text { increase in demand } \\
\text { through a network- } \\
\text { wide adoption of the } \\
\text { cloud-based operating } \\
\text { system from EDUCATE. }\end{array}$ & $\begin{array}{l}\text { Maintaining and further } \\
\text { developing the relationship } \\
\text { with the local tinkerer } \\
\text { community to provide } \\
\text { flexibility and additional } \\
\text { capacity. }\end{array}$ & $\begin{array}{l}\text { The pandemic highlighted } \\
\text { the synergies of network } \\
\text { participants and the ability } \\
\text { to respond quickly not only } \\
\text { to changes in demand but } \\
\text { to develop, make and } \\
\text { supply novel solutions to } \\
\text { problems. }\end{array}$ \\
\hline
\end{tabular}

Following the PPE supply chain shortages, the cluster continued to develop IT systems to provide an agile and flexible approach to managing capacity internally and externally. By working closely together during the pandemic the cluster members had strengthened their relationships and the transparency of their 
objectives and ambitions for the group. Socio-political complexities had been addressed quickly, supported by IT improvements. However, they realised that future progress would be dependent on identifying new business opportunities and possible expansion of manufacturing members. These two issues were emerging as the main concerns of the cluster at this stage in its development.

\subsection{Discussion}

In 2020 the Covid-19 pandemic severely disrupted the supply of Personal Protective Equipment (PPE) due to surges in demand and supply issues from China. This research examined the formation and development of a geographic cluster which responded to the supply crisis through additive manufacturing (AM). During the pandemic, the cluster transformed from a loosely constructed arrangement into a dynamic and highly focused network for the production of PPE. The type and nature of exchanges between the organizations involved in the cluster, before, during and after the supply chain disruption caused by Covid-19 were found to have changed significantly in terms of structural, socio-political and emergent dimensions (Turner et al., 2018).

From a structural complexity perspective, the loose collection of organizations rapidly formalized their movement of product and information flows to ensure a quick and reliable supply of PPE, responding to the supply chain disruption opportunity in a synchronized manner compared to the largely reactive and uncoordinated approach of governments and larger corporations (Rapaccini et al, 2020). The geographical closeness of the cluster facilitated the development of "buzz" between members (Novak and Choi, 2015) and a positive problem-solving approach aimed at meeting the demands and uncertainties of Covid-19. The role of the University was pivotal, as the sponsor, in developing the management skills, operation parameters and knowledge exchange mechanisms that underpinned the cluster (Fraser and Kelly, 2010). All cluster entities employed resources that previously worked at UNI-R\&D in an AM capacity. To ensure that the learning and coherence gained during the pandemic was not dissipated, as the cluster evolved, an "on-boarding" process was developed for new potential cluster members which complemented the network (Dedehayir et al. 2018). This process included participation in workshops as well as having the ability to integrate their resources, seamlessly, through a cloud-based system. These steps were planned to ensure compatibility of approach as well as flexibility through integrated capacity.

The socio-political dimension altered significantly as Covid-19 materialized in the local community. The formal bilateral arrangement to managing demand was replaced by a highly coordinated University-led approach which distributed commercial work to all cluster members (Chetty et al., 2008). The change from a bilateral to cluster approach reflected the societal response of its members to the pandemic. Individual commercial priorities were suspended in a drive to meet the PPE needs of local clinicians and healthcare workers. This societal crisis-led initiative was mirrored by the response of the tinkerer community who volunteered, free of charge, their AM capacity. Incorporation of the local tinkerer capacity increased the flexibility of the cluster as well as highlighting the wider community need to help during the crisis. The challenge for the cluster members was the poor quality of the tinkerer and student outputs which had to be managed during the pandemic and post. Maintaining the interest and enthusiasm of the tinkerer community as suppliers of capacity as well as potential customers of future service 
offerings was recognized as a challenge by members. Following the initial decline of the pandemic in Australia, tensions appeared in the cluster. Credit and media attention given to individual members overshadowed their joint achievements, affecting its cohesiveness. This Covid-19-initiated societalfocused buzz within the cluster started to diminish and began to be replaced by individual commercial needs. One of the future challenges for the expanding cluster is the development of a buzz that provides a cohesive longer-term reason for operating in a strongly coordinated network.

During the development of the cluster several issues emerged which required adaptation of processes and procedures. Initially some of the loosely coupled organizations were skeptical about the fairness of work allocation and ownership of intellectual property. The lack of transparency between members and the informal approach to the planning of work exacerbated concerns. The Covid-19 pandemic led to the transformation of the interactions from guarded to open and collaborative (Samuel et al., 2011). The unknowns of the coronavirus in terms of impact and severity led the geographically close organizations to alter rapidly their processes to improve product design and gain approval from government. Improving product architecture has been shown to support resourcing during pandemic supply chain disruption (Elsahn and Siedlok, 2021). The agility demonstrated by the cluster reflected their shared concerns about the consequences of Covid-19 and their desire to make a difference. This led to a two-day product turnaround rather than months. This positive experience has developed confidence in the cluster to address future challenges. The potential loss of PPE business, as their customers move from an agile to lean supply position, is being viewed as an opportunity to help other businesses' onshore manufacturing, reflecting theory that some improve under stress (Rittera and Pedersen, 2020). The flexible and responsive approach developed under Covid-19, as well as the media promotion highlighting this strength, provides a platform to grow the cluster.

Research has delineated the components required for the development of clusters. However, the mechanisms required to enact these are rarely discussed beyond the geographical and governmental/regional investment aspects (Vernay et al., 2018). The coopetitive approach that developed during the emergency (Schiffling et al., 2020) was beginning to alter traditional competitive relationships. The detail of how to transform a collection of independent organizations into a unified and coherent interdependent community and supply chain has begun to be revealed through this case study. The cluster's progression and development was forged through specific enablers, which we explore further below.

Localization of Demand: the onshoring of PPE production created an unexpected and time critical window to localize demand for AM (Ingstrup et al., 2017). The speed of response and flexibility of the AM cluster to meet the demand surge required a different approach to coordination and interaction. With many countries and companies across the globe reflecting on the resilience of their supply chain, following Covid-19, AM proffers the opportunity to reduce risk.

This leads us to the following proposition:

Proposition 1: AM clusters are more likely to form in response to situations in which demand surges are time-critical and subject to increased "Buzz" (the intensive interaction and sharing of knowledge among AM cluster members) 
The pattern of events leading up to the growth of the cluster was promoted by the rapid need for PPE that arose in the period following the supply chain disruption. Political, media, and national attention led to the need for a response, and the demand for masks led to firm orders that promoted the investments in activity. Whilst the Covid response was the initial driver, the sustainability of the cluster was ensured by the need for on-going activity related to the recognition that national security and supply chain independence from Asian PPE producers was becoming important. This was related to a second enabler which also highlighted the surge in demand.

Buzz: the importance of generating buzz through intense interaction and development of a knowledge-based ecosystem has been shown to be pivotal (Bathelt et al., 2004). The pandemic emergency created a focal point for the AM cluster demonstrating the importance of identifying an objective that provides the impetus for a coordinated approach. Overcoming the obstacles that hinder alignment of organizations and their drive to deliver customer value through the multi-faceted and flexible resources of a cluster is critical in their development. The case study through its demonstration of the benefits and potential of working as a unified and coordinated cluster is beginning to switch the buzz from a societal generated need to a commercial opportunity.

In a sense, "buzz" involves the aligned recognition by distinct members of the cluster that a "coming together" is underway, promoting a team spirit that promotes the idea that "we are all in this together". This relational artifact among members of a cluster, it turns out, appears to be a catalyst for activity that creates synergies and aligned efforts. "Buzz" represents a type of 'social capital' (Petersen et al., 2008) that serves as an important ingredient in the formation and success of industrial clusters, and aids in reducing complexity. This attribute needs to be explored further, to understand how to promote buzz during early formative cluster stages.

Societal Support: One of the unique aspects of the AM case study is the involvement of the public in the achievements and objectives of the cluster during the pandemic. The speed of response and the rapid growth in demand led to the cluster expanding its boundaries to include the local community. Leveraging social capital (Corsini et al, 2021), tinkerers were integrated, temporarily, into the cluster leading to an increase in capacity. Though there were quality issues that arose early on with tinkerer outputs, this experience demonstrates the universality of $A M$ as a technology that can expand across the ecosystem it operates within. As a result of this experience, this particular cluster recognized the need to improve the quality of the tinkerer community, and established training opportunities to further address this shortfall. Developing the capabilities of the tinker community facilitates accessing new opportunities especially when the target product has an architecture that is modular or has low product complexity (Elsahn and Siedlok, 2021). This level of engagement recognizes how clusters can become more integrated with the local business community, and the important role it plays in the context of humanitarian disaster responses employing emerging technologies. The cluster continues to embrace this model as a future opportunity and way of working when faced with other capacity challenges.

This leads us to the following proposition:

Proposition 2: Interaction with the local community through communication and engagement with local actors is an important driver in AM cluster success. 
In effect, the "tinkerer" community represents a localization of the supply chain (Corsini et al, 2021) and a source of innovation that allows individuals to experiment with the technology, develop new applications and products, and explore the limits of AM across different supply chains. This source of new ideas should be welcomed and nurtured in the early stages of AM cluster development, as these individuals provide access to potential sources of new market and new product development ideas.

Composition: The composition of the cluster is a critical enabler of success and/ or failure. AM has progressed and matured as a technology, however industry-wide uptake is still in its infancy. In regional Australia, businesses adopting AM technology as a core element of their strategy are predominantly SMEs. Government, through encouraging and enticing collaboration and knowledge sharing, can enable complementary network activities (Elsahn and Siedlok, 2021). The local University took on the role of sponsor, cluster coordinator and provider of technical support for this emerging technology (Pan, 2019). The sponsor from the outset of the cluster provided a neutral central governance mechanism for AM knowledge dissemination and cluster coordination, serving as an important guardrail to prevent perceived inequities in commercial outcomes. Through workshops and training the sponsor supported the transition of the cluster from a loose collection to a structurally coordinated cluster. Another important guardrail for structural problems, developed by the sponsor to avoid direct competitive issues, was that the AM entities that were invited into and joined the cluster catered to different market segments, therefore reducing direct market competition. Finally, the fact that all cluster members have historical ties to the sponsor (local University) and operated within close proximity with one other led to increased trust, simplified coordination, and aligned expectations. The role of the sponsor changed during the case study from being a provider of technical support and education to a coordinator and governance provider that guided the development of the cluster to minimize dysfunctionality between members.

This leads us to the following proposition:

Proposition 3: Interaction with the local community led by a sponsor providing a coordinating mechanism contributes to AM cluster success.

In a sense, the University served as a sponsor and neutral third party that was seen as an unequivocal member of the community. It could address perceived inequities, challenges to fair proceedings, and other relationship-related issues that arise in a cluster of any sort. The fact that many of the AM cluster members had ties to the University also promoted the sense of loyalty and recognition of its role as a higher authority that could govern the operational challenges of the cluster.

Balancing Structure and Relationship Development: The longitudinal data in the case highlighted that a mutual understanding among cluster members existed prior to the pandemic outbreak. All cluster entities deployed resources recognizing a strong affiliation to UNI-R\&D and informal relationships that were already in place. During the Covid-19 outbreak this loosely coupled network began to become more concrete in nature, leading to more formalized structures, contractual obligations, and formal coordination mechanisms. These structures and governance mechanisms laid the foundation for the ensuing rapid growth of the cluster that occurred during the pandemic. Informal ways of working in the early formation stage of the cluster migrated into a more formalized structure, which was important in establishing the basis for strong growth. The 
sponsor, through the development of a governance structure which supported the cluster, also recognized the need for 'fuzziness' in the guidelines to allow the member organizations the space to explore other possibilities. This was viewed as important for the sustainability of the cluster as well as individual participants.

This leads us to the following proposition:

Proposition 4: Informal relationships are critical to the formation and initial growth of the cluster; further strengthening of ties is later supported by more formal mechanisms as the size of the cluster increases and coordination can no longer be achieved purely through informal methods.

The complexity framework we used in our analysis has provided a number of important insights. Although the broad trend we observed was from an informal to a more formal and controlled approach, it is interesting that in the three phases covered we identified a variety of complexity issues in every one of the nine complexity/response categories. The framework and our analysis suggest that initiating and developing a successful cluster is indeed a complex undertaking, and requires an ability to deal with rapid change and a variety of different challenges that arise in an unpredictable fashion. As such, it is difficult to come away with a singular "template" for success, which may also explain why we do not find a large number of successful clusters in industry.

The complexity analysis highlights how technical and organizational (structural) difficulties need to be overcome through both planning and social mechanisms. Socio-political and emergent issues can also hamper progress and similarly need effective resolution. The nature of the cluster means that there is no single point of responsibility and authority, but (some degree of) distributed leadership which will likely alter over time. This indicates that the challenges for managers, considering the formation of a cluster to respond to humanitarian disasters and emerging technologies, are multifaceted - they must be able to negotiate a range of difficulties, including, but certainly not limited to, the technology being developed. As far as we aware this is the first time that the Maylor and Turner (2017) framework has been used in a longitudinal study, and it highlights clearly the evolving nature of the complexities faced.

\subsection{Implications}

Forming and developing an AM cluster provides both opportunities and challenges to institutions and businesses. Fraser and Kelly's (2010) research highlighted several cluster components that are critical in the success of the network. This research confirmed the importance of knowledge transfer, coordination and leadership within clusters. The emergence of local demand, for example through PPE shortages, was also found to be critical in developing a "buzz" and alignment of focus for cluster members. The findings also give more detail of the challenges and evolution over time of member goals, relationship interdependence, and governance, as identified by Bogers et al. (2019).

The longitudinal study, however, surfaced issues that are not covered to any great extent in the cluster literature. The formation of clusters, generally, focuses on the sharing of knowledge. However, the transformation of a cluster into a viable entity requires substantive commercial development. The supply 
chain disruption of the case study provided the impetus for the rapid commercialization of the AM cluster. This highlighted the ability of the cluster to respond and react quickly to commercial opportunities that arose. This research has revealed the synergetic importance of developing commercial as well as technical skills and knowledge in clusters. Universities and/or government institutions need to be cognizant of commercial as well as technical/knowledge transfer activities for clusters to become sustainable.

The accessibility of AM technology to the wider community demonstrates the pervasive nature of the technology. AM provides the opportunity for clusters to engage at the individual as well at the business level. Realizing income streams that will create and deliver value to the investing organizations and end users challenges clusters in their exploitation of IT platforms. The case study organizations recognized that sustainment of the network necessitated the development of an infrastructure to support information flows, design transfers and capacity management. Government agencies and private businesses should be considerate of the IT implications of AM in the management and development of a cluster. Ensuring information flows within and across cluster boundaries is important for supply chain managers as they examine the resilience of global chains and the risk reduction benefits of AM. This is particularly pertinent when AM is expected by 2040 to reduce global trade flows by $40 \%$ (Economist, 2020).

Cluster evolution over time (in this case, quite dramatically) can lead to difficulties for managers in the different cluster organizations as relationships and requirements change. Our longitudinal use of the complexity analysis technique was beneficial in understanding the nature of the issues and the steps taken, and how these altered over time. We have used these complexity ideas with experienced students in Masters and executive education classes, and the feedback from participants is that they recognize the utility of the method and find it beneficial in analyzing their own situations and practice. Using such a framework may be helpful for managers in clusters to meet at regular intervals to understand their - and others' - structural, socio-political and emergent complexities. Through this structured dialogue they may be more able to address current and anticipated complexity responses with greater effectiveness and jointly negotiate the evolution of the cluster more coherently than would otherwise be the case.

Future research would be beneficial in examining further some of these issues. Specifically, the factors that create 'buzz' are as yet not fully understood, and a better understanding of what does and does not support this would be helpful. Similarly, the factors that sustain AM clusters over the longer term, together with their role and timing, are also unclear. Further longitudinal studies would enable a greater understanding of the lifecycle of how such instances grow, stabilize, decay or thrive. This information is important both for the organizations involved and also for those looking to support them, such as governments.

\subsection{Conclusion}

This longitudinal case study focuses on an additive manufacturing cluster which was established to supply PPE in a responsive and flexible manner. It offered a unique opportunity to gather data over three stages of the cluster: interactions between actors prior to the supply chain disruption caused by Covid-19 arrival in Australia; during the pandemic; and post the decline of the virus and stability of PPE supply in the region. This research has demonstrated that the development of geographical clusters to support localization of supply provides an alternative supply option. Success factors for the creation of the manufacturing cluster 
in this particular case have been identified. Clustering of local businesses creates opportunity for the development of an information and communication ecology to support the development of "buzz", and evolves to a competitive advantage through collaboration and coordination of resources. The findings from this research proffer some generalizable insights into cluster formation and evolution in terms of structural, socio-political and emergent dimensions. The challenges and enablers identified provide a basis for the future responses to the coordination and exploitation of new technologies through clusters. The rapid and agile approach to addressing the Covid-19 supply crisis also illuminates the potential for the role of AM in future disaster response. A wider analysis of AM producers' actions in 2020 and beyond would appear to be an important area for both manufacturers and user organizations such as humanitarian agencies, healthcare providers, and governments.

This explorative longitudinal field investigation is not without limitations. Further research is required to enhance generalisability of the research and test the emerging propositions developed. However, despite the limitations, the research highlights that great opportunities exist in the area of onshoring, cluster development and localisation of agile manufacturing. Further research is also required to understand the role of innovative clusters to enhance supply chain resilience.

\section{Acknowledgements:}

Funding from the Australian Research Council Centre of Excellence Scheme (Project Number CE 140100012 ) is gratefully acknowledged.

The authors would like to thank the Australian National Fabrication Facility (ANFF) - Materials node for access to services and equipment.

\section{References}

3D Printing Industry (2020a)

https://3dprintingindustry.com/news/analyzing-the-economic-impact-of-the-neighborhood-91-additivemanufacturing-hub-at-pittsburgh-international-airport-167286/ (accessed on 22.06.2020)

3D Print (2020)

https://3dprint.com/256036/additive-manufacturing-open-cluster-in-bavaria-oerlikon-ge-additive-linecollaborate/ (accessed on 19.06.2020)

3D Printing Industry (2020b).

(https://www.3dprintingbusiness.directory/company/national-additive-manufacturing-innovationcluster-namic/ (accessed on 19.06.2020)

Aage, T. and Belussi, F. (2008), "From fashion to design: creative networks in industrial districts", Industry and innovation, Vol. 15 No. 5, pp.475-491. 
Ackoff, R. (1979), "The future of operational research is past", Journal of the Operational Research Society, Vol. 30 No. 2, pp.93-104.

Ahn, M. J., \& Meeks, M. (2008). "Building a conducive environment for life science-based entrepreneurship and industry clusters", Journal of Commercial Biotechnology, Vol. 14 No. 1, pp 20-30.

Aitken, J., Bozarth, C. and Garn, W. (2016), "To Reduce or Absorb Supply Chain Complexity: A Conceptual Model and Case Study", Supply Chain Management: An International Journal, Vol. 21 No. 6 pp.759-774

Albert, M.G. (2017), "Entrepreneurship, innovation and regional performance: application for the Spanish regions", Entrepreneurship and Regional Development, Vol. 29 No. 3-4, pp.271-291.

Battaglia, D., Paolucci, E. and Ughetto, E., (2021). "The fast response of academic spinoffs to unexpected societal and economic challenges. Lessons from the COVID-19 pandemic crisis", R\&D Management, Vol. 51 No. 2, pp.169-182.

Bathelt, H., Malmberg, A. and Maskell, P. (2004), "Clusters and knowledge: local buzz, global pipelines and the process of knowledge creation.", Progress in Human Geography, Vol. 28 No. 1, pp.31-56.

Beamon, B.M. (2004, November), "Humanitarian relief chains: issues and challenges.", In Proceedings of the 34th International Conference on Computers and Industrial Engineering, Vol. 34, pp.77-82. Seattle, WA: University of Washington.

Bititci, U.S., Martinez, V., Albores, P. and Parung, J. (2004), "Creating and managing value in collaborative networks", International Journal of Physical Distribution \& Logistics Management, Vol. 34 No. 3/4, pp.251-268.

Bogers, M., Sims, J. and West, J., (2019) "What Is an Ecosystem? Incorporating 25 Years of Ecosystem Research", Academy of Management Proceedings, Vol. 2019, No. 1,

Bozarth, C., Warsing, D., Flynn, B. and Flynn, J. (2009), "The impact of supply chain complexity on manufacturing plant performance”, Journal of Operations Management, Vol. 27 No. 1, pp78-93.

Breschi, S. and Beaudry, C. (2003), "Are firms in clusters really more innovative?", Economics of Innovation and New Technology, Vol. 12 No. 4, pp.325-342.

Bresnahan, T., Gambardella, A. and Saxenian, A. (2001), "'Old economy' inputs for 'new economy' outcomes: Cluster formation in the new Silicon Valleys.", Industrial and Corporate Change, Vol. 10 No. 4, pp.835-860.

Chetty, S. and Agndal, H. (2008), "Role of Inter-organizational Networks and Interpersonal Networks in an Industrial District", Regional Studies, Vol. 42 No. 2, pp.175-187.

Chetty, S., Karami, M., and Martín, O. M. (2018), "Opportunity discovery and creation as a duality: Evidence from small firms' foreign market entries.", Journal of International Marketing, Vol. 26 No. 3, pp.70-93.

Cicmil, S., Cooke-Davies, T., Crawford, L., and Richardson, K. (2009), "Exploring the Complexity of Projects: Implications of Complexity Theory for Project Management Practice", Project Management Institute. 
Clay-Williams, R., Rapport, F. and Braithwaite, J., (2020). "The Australian health system response to COVID-19 from a resilient health care perspective: what have we learned?". Public Health Research and Practice., Vol. 30 No. 4, e3042025

Colovic, A., (2019), "Cluster connectivity and inter-cluster alliance portfolio configuration in knowledgeintensive industries.",M@n@gement,pp.619-635.

Corsini, L., Dammicco, V. and Moultrie, J., (2021)."Frugal innovation in a crisis: the digital fabrication maker response to COVID-19”. R\&D Management, Vol. 51 No. 2, pp.195-210.

Crespo, J., (2011), "How Emergence Conditions of Technological Clusters Affect Their Viability?

Theoretical Perspectives on Cluster Life Cycles", European Planning Studies, Vol. 19 No. 12, pp.20252046.

Cui, Z., Ouyang, T., Chen, J. and Li, C. (2019) "From peripheral to core: a case study of a 3D printing firm on business ecosystems reconstruction", Technology Analysis \& Strategic Management, Vol. 31 No. 12, pp1381-1394.

Daghar, A., Alinaghian, L. and Turner, N. (2021) "The role of collaborative interorganizational relationships in supply chain risks: a systematic review using a social capital perspective", Supply Chain Management: an International Journal, Vol 26 No. 2, pp.279-296.

Dedehayir, O., Mäkinen, S.J. and Ortt, J.R., (2018). "Roles during innovation ecosystem genesis: A literature review". Technological Forecasting and Social Change, Vol. 136, pp.18-29.

Dedehayir, O., Ortt, R. J., Mäkinen, S.,J., \& Chakrabarti, A. (2016). "The process of ecosystem genesis: A tale of two drugs" Manchester: The International Society for Professional Innovation Management (ISPIM). Porto, Portugal on 19-22 June

de Leeuw, S., Grotenhuis, R. and van Goor, A. (2013), "Assessing complexity of supply chains: evidence from wholesalers", International Journal of Operations \& Production Management, Vol. 33 No. 8, pp. 960-980.

deWitt, T, Giunipero, LC and Melton, HL (2006), "Clusters and supply chain management: the Amish experience", International Journal of Physical Distribution \& Logistics Management, Vol. 36 No. 4, pp.289-308.

Elsahn, Z. and Siedlok, F., (2021). "“'Can we build it? Yes, we can!” complexities of resource redeployment to fight pandemic", Industrial Marketing Management, Vol. 93, pp.191-207.

Engel, J. S. (2015). "Global clusters of innovation: Lessons from Silicon Valley", California Management Review, Vol. 57 No. 2, pp 36-65.

Finegold, D. (1999) "Creating self-sustaining, high-skill ecosystems", Oxford Review of Economic Policy, Vol. 15 No. 1, pp.60-81

Fornahl, D., Henn, S. and Menzel, M.P. (2010), Emerging clusters: theoretical, empirical and political perspectives on the initial stage of cluster evolution. Edward Elgar Publishing. 
Fraser, M., and Kelly, S. (2010), "The creation and growth of Information Technology Communication (ICT) industrial clusters: The New Zealand case.", New Zealand Journal of Applied Business Research, Vol. 8 No. 1, pp.15-26

Friar, J.H., and Meyer, M.H. (2003), "Entrepreneurship and start-ups in the Boston region: Factors differentiating high-growth ventures from micro ventures", Small Business Economics, Vol. 21 No. 2, pp.145-152.

Gawer, A. (2014). "Bridging differing perspectives on technological platforms: Toward an integrative framework." Research Policy Vol. 43 No. 7, pp 1239-1249.

Geraldi, J., Maylor, H. and Williams, T. (2011), “Now, let's make it really complex (complicated): A systematic review of the complexities of projects", International Journal of Operations \& Production Management, Vol. 31 No. 9, pp.966-990.

Gries, T., and Naude, W. (2009), "Entrepreneurship and regional growth: towards a general theory of start-ups", Innovation - The European Journal of Social Science Research, Vol. 22 No. 3, pp.309-328.

Handfield, R.B., Graham, G. and Burns, L. (2020), "Corona virus, tariffs, trade wars and supply chain evolutionary design", International Journal of Operations \& Production Management, Vol. 40 No. 10, pp.1649-1660.

Hammervoll, T, Halse, LL and Engelseth, P. (2014), "The role of clusters in global maritime value networks", International Journal of Physical Distribution \& Logistics Management, Vol. 44 No. 1/2, pp.98-112.

Hassink, R. (2005), “How to unlock regional economies from path dependency? From learning region to learning cluster", European Planning Studies, Vol. 13 No. 4, pp.521-535.

Hayter, C. S. (2016) "A trajectory of early-stage spinoff success: the role of knowledge intermediaries within an entrepreneurial university ecosystem", Small Business Economics, Vol. 47, No. 3, pp 633-656.

Henn, S. and Bathelt, H., (2018), "Cross-local knowledge fertilization, cluster emergence, and the generation of buzz.", Industrial and Corporate Change, Vol. 27 No. 3, pp.449-466.

Huang, B and Xue, X (2012), "An application analysis of cluster supply chain: a case study of JCH", Kybernetes, Vol. 41 No. 1/2, pp.254-280.

Ingstrup, M., Jensen, S. and Christensen, P. (2017), "Cluster evolution and the change of knowledge bases: the development of a design cluster", European Planning Studies, Vol. 25 No. 2, pp.202-220.

Jacobides, M. G., Cennamo, C., and Gawer, A. (2018) "Towards a theory of ecosystems", Strategic Management Journal, Vol. 39 No.8, pp2255-2276.

John, L., Ramesh, A. and Sridharan, R., (2012), "Humanitarian supply chain management: a critical review.", International Journal of Services and Operations Management, Vol. 13 No. 4, pp.498-524.

Jin, Y., Ji, S., Li, X. and Yu, J. (2017), "A scientometric review of hotspots and emerging trends in additive manufacturing", Journal of Manufacturing Technology Management, Vol. 28 No. 1, pp.18-38. 
Kapoor, R. and Lee, J. M. (2013) "Coordinating and competing in ecosystems: How organizational forms shape new technology investments", Strategic Management Journal, Vol. 34 No. 3, pp274-296.

Kayvanfar, V., Husseini, S.M., NengSheng, Z., Karimi, B. and Sajadieh, M.S., (2019), "A practical supplydemand hub in industrial clusters: a new perspective". Management Research Review. Vol. 42 No. 1, pp. 68-101

Kivimaa, P., Boon, W., Hyysalo, S., \& Klerkx, L. (2019). "Towards a typology of intermediaries in sustainability transitions: A systematic review and a research agenda". Research Policy, Vol. 48, No. 4, pp.1062-1075.

Koster, S., van Stel, A., and Folkeringa, M.N., (2012), "Startups as drivers of market mobility: an analysis at the region-sector level for The Netherlands", Small Business Economics, Vol. 39 No. 3, pp.575-585.

Kovács, G. and Spens, K.M., (2007), "Logistics theory building.", The Icfai Journal of Supply Chain Management, Vol. 4 No. 4, pp.7-27.

Kwak, K., Kim, W. and Park, K. (2018) "Complementary multiplatforms in the growing innovation ecosystem: Evidence from 3D printing technology" Technological Forecasting \& Social Change, Vol. 135 No. 1, pp.192-207.

Maylor, H. and Turner, N.W. (2017), “Understand, reduce, respond: project complexity management theory and practice", International Journal of Operations \& Production Management, Vol. 37 No. 8, pp.1076-1093.

Maylor, H.R., Turner, N.W. and Murray-Webster, R. (2013), "How hard can it be?: Actively managing complexity in technology projects", Research Technology Management, Vol. 56 No. 4, pp.45-51

McCutcheon, D.M. and Meredith, J.R. (1993), "Conducting case study research in operations management.", Journal of Operations Management, Vol. 11 No. 3, pp.239-256.

McPhillips, M., (2020). "Innovation by proxy-clusters as ecosystems facilitating open innovation. Journal of Entrepreneurship", Management and Innovation, Vol. 16, No. 3, pp.101-128.

Mohr, S. and Khan, O. (2015), "3D printing and its disruptive impacts on supply chains of the future.", Technology Innovation Management Review, Vol. 5 No. 11, pp.20.

Nestle, V., Täube, F. A., Heidenreich, S., \& Bogers, M. (2019). “Establishing open innovation culture in cluster initiatives: The role of trust and information asymmetry". Technological Forecasting and Social Change, Vol. 146, pp 563-572.

Novak, D.C. and Choi, T.Y. (2015), "The Role of Geography in Shaping SCM's Professional Identity", Journal of Business Logistics, Vol. 36 No. 2, pp.231-232.

Oh, D.S., Phillips, F., Park, S. and Lee, E., (2016). "Innovation ecosystems: A critical examination", Technovation, Vol. 54 No. 1, pp.1-6

Ohio AM (2020), https://neohioamcluster.org/ (accessed on 22.06.2020) 
Pan, S. (2019). "Business Clustering in New Zealand: The Creation of Competitiveness in a Regional Cluster and The Influences of Intermediaries on the Cluster Competitiveness", Doctoral dissertation, Auckland University of Technology.

Papalexi, M., Bamford, D. and Breen, L. (2020), "Key sources of operational inefficiency in the Pharmaceutical Supply Chain.", Supply Chain Management: An International Journal, Vol.25 No. 6, pp.617-635.

Parker, G., van Alstyne, M. V., \& Jiang, X. (2017). "Platform ecosystems: How developers invert the firm". Management Information Systems Quarterly, Vol. 41 No. 1, pp 255-266.

Petersen, K., Handfield, R., Lawson, B. and Cousins, P. (2008), "Buyer Dependency and Relational Capital Formation: The Mediating Effects of Socialization Processes and Supplier Integration.", Journal of Supply Chain Management, Vol. 44 No. 4, pp.53-65.

Polenske, K.R .(2004), “Competition, collaboration and cooperation: An uneasy triangle in networks of firms and regions", Regional Studies, Vol. 38 No. 9, pp.1029-1043.

Porter, ME (1998), On competition, Harvard Business School, Boston.

Porter, M. E. (2000). "Location, competition, and economic development: Local clusters in a global economy". Economic Development Quarterly, Vol. 14, No. 1, pp 15-34.

Rapaccini, M., Saccani, N., Kowalkowski, C., Paiola, M. and Adrodegari, F., (2020). "Navigating disruptive crises through service-led growth: The impact of COVID-19 on Italian manufacturing firms". Industrial Marketing Management, Vol. 88, pp.225-237.

Ritter, T. and Pedersen, C.L., (2020) "Analyzing the impact of the coronavirus crisis on business models". Industrial Marketing Management, Vol. 88, pp.214-224.

Rong, K., Lin, Y., Yu, J. and Zhang, Y. (2020) “Manufacturing strategies for the ecosystem-based manufacturing system in the context of 3D printing", International Journal of Production Research, Vol. 58 No. 8, pp.2315-2334

Rylands, B., Böhme, T., Gorkin, R., Fan, J. and Birtchnell, T. (2016), "The adoption process and impact of additive manufacturing on manufacturing systems.", Journal of Manufacturing Technology Management, Vol. 27 No. 7, pp.969-989.

Samuel, KE., Goury, M-L, Gunasekaran, A. and Spalanzani, A. (2011), "Knowledge management in supply chain: An empirical study from France", The Journal of Strategic Information Systems, Vol. 20 No. 3, pp.283-306.

Schiffling, S., Hannibal, C., Fan, Y. and Tickle, M. (2020), "Coopetition in temporary contexts: examining swift trust and swift distrust in humanitarian operations", International Journal of Operations \& Production Management, Vol. 40 No. 9, pp.1449-1473.

Serdarasan, S. (2013), "A review of supply chain complexity drivers", Computers \& Industrial Engineering, Vol. 66 No. 3, pp.533-540. 
Smedlund, A. (2006), "The roles of intermediaries in a regional knowledge system.", Journal of Intellectual Capital, Vol. 7 No. 2, pp.204-220.

Steinburg, P. F. (2015), “Can we generalize from case studies?”, Global Environmental Politics, Vol. 15, No. 3, pp.152-175.

Tatham, P., Loy, J. and Peretti, U., (2015), "Three dimensional printing-a key tool for the humanitarian logistician?", Journal of Humanitarian Logistics and Supply Chain Management, Vol. 5, No. 2, pp.188-

208.

The Economist, (2020), “Onshoring supply chains", The Economist. 2020 December 19, p.108

Tolossa, NJ., Beshah, B., Kitaw, D., Mangano, G. and De Marco, A. (2013), "A Review on the Integration of Supply Chain Management and Industrial Cluster", International Journal of Marketing Studies, Vol. 5 No. 6, pp.164-174.

Turner, N., Aitken, J. and Bozarth, C., (2018), "A framework for understanding managerial responses to supply chain complexity", International Journal of Operations \& Production Management, Vol. 38, No. 6, pp.1433-1466.

Vargo, S.L. and Lusch, R.F. (2017), "Service-dominant logic 2025", International Journal of Research in Marketing, Vol. 34, No. 1, pp.46-67.

Vernay, A.L., D'Ippolito, B. and Pinkse, J. (2018), “Can the government create a vibrant cluster? Understanding the impact of cluster policy on the development of a cluster.", Entrepreneurship \& Regional Development, Vol. 30, No. 7-8, pp.901-919.

Voss, C., Tsikriktsis, N., and Frohlich, M., (2002), "Case research in operations management", International Journal of Operations \& Production Management, Vol. 22 No. 2, pp.195-219.

Webb, E., Campbell, D.T., Schwartz, R.D., and Sechrest, L., (1966), Unobtrusive measures: Nonreactive research in the social sciences, Rand-McNally, Chicago, USA.

Williams, T., (2005). "Assessing and Moving on From the Dominant Project Management Discourse in the Light of Project Overruns", IEEE Transactions on Engineering Management, Vol. 52, No. 4, pp.497508.

Yin, R.K., (2014), Case study research - Design and methods, 5th Edition, Sage Publications, California, USA. 